\title{
Still Floating: Security-Based Swap Agreements After Dodd-Frank
}

\author{
Thomas J. Molony
}

\section{INTRODUCTION}

Shortly before the United States Congress enacted the DoddFrank Wall Street Reform and Consumer Protection Act ("DoddFrank"), Senator Christopher Dodd, then-Chairman of the Senate Banking Committee, suggested that no one will know how the law will work until it becomes effective. ${ }^{2}$ The same might have been said almost ten years earlier about the provisions with respect to securitybased swap agreements included in the Commodity Futures Modernization Act of $2000^{3}$ (CFMA). The CFMA defined the term "securitybased swap agreement" for purposes of, among other things, the general antifraud provisions of the Securities Act of $1933^{4}$ (the "Securities Act") and the Securities Exchange Act of $1934^{5}$ (the "Exchange Act"). Now, more than ten years after the CFMA was enacted, it remains unclear what the term means and how far it extends.

In a swap agreement, parties agree to exchange payments determined with reference to a quantity of a specified asset. ${ }^{6}$ This quan-

\footnotetext{
* Assistant Professor, Elon University School of Law. I would like to thank Steve Bradford, Tom Hazen, and Alan Palmiter for their helpful suggestions and comments and Nathan Standley and Marie Anders for their research and editorial assistance. All errors and omissions, of course, are my own.

${ }^{1}$ Pub. L. No. 111-203, 124 Stat. 1376 (2010) (to be codified in scattered sections of the U.S. Code).

${ }^{2}$ David Cho, Jia Lynn Yang \& Brady Dennis, Lawmakers Guide Dodd-Frank Bill for Wall Street Reform into Homestretch, WASH. POST (June 26, 2010), http://www.washingtonpost.com/wp-dyn/content/article/2010/06/25/AR20100 62500675.html.

${ }^{3}$ Pub. L. 106-554, 114 Stat. 2763A-365 (codified in scattered sections of 7, 11, 12, and 15 U.S. Code). The CFMA was enacted as part of the Consolidated Appropriations Act of 2001, Pub. L. No. 106-554, 114 Stat. 2763 (2000) (codified in scattered sections of the U.S. Code).

${ }^{4} 15$ U.S.C. $\$ \S 77 a-77$ aa $(2006)$.

5 Id. $\$ \S 78 \mathrm{a}-78 \mathrm{nn}$.

${ }^{6}$ Roberta Romano, A Thumbnail Sketch of Derivative Securities and Their Regulation, 55 MD. L. REV. 1, 46 (1996).
} 
tity is referred to as the "notional" amount, and the notional amount itself typically is not exchanged.

Swaps take many different forms, vary in complexity, and are used for different purposes. ${ }^{8}$ Perhaps the simplest form is an interest rate swap. In an interest rate swap, the parties agree to exchange payments calculated by multiplying interest rates by a notional amount equal to an amount of money.

Borrowers often use interest rate swaps to hedge against the risk of changes in interest rates. ${ }^{9}$ For example, a borrower who is obligated on a $\$ 1$ million loan that bears interest at a variable rate per annum equal to the London Interbank Offered Rate (LIBOR) ${ }^{10}$ is subject to changes in LIBOR. If LIBOR averages four percent during a year, the borrower's annual financing cost is $\$ 40,000$. If LIBOR averages eight percent, the borrower pays $\$ 80,000$. To eliminate the risk of changes in LIBOR, the borrower might enter into a floating-tofixed interest rate swap. Under the swap, the borrower would agree to make periodic payments determined by multiplying a "fixed rate" of, perhaps, six percent per annum by a notional amount equal to $\$ 1$ million, the outstanding principal under the loan. In exchange, the other party-known as the counterparty-would agree to make periodic payments determined by multiplying a "floating rate" of LIBOR by the notional amount. ${ }^{11}$ By entering into the swap, the borrower fixes its annual net financing cost at $\$ 60,000$. If LIBOR averages four percent during a year, the borrower's net financing cost is $\$ 60,000$. $^{12}$

${ }^{7} I d$.

8 See Philip McBride Johnson \& Thomas Lee Hazen, Derivatives Regulation $\S 1.02$ [8], at 56 (2004) (indicating that swaps generally are used to hedge risks, but also may be used for "purely speculative purposes").

9 See id. (noting that swaps are used as hedges against "the risk of adverse changes in interest rates").

10 The London InterBank Offered Rate is produced for ten currencies with 15 maturities quoted for eachranging from overnight to 12 months-thus producing 150 rates each business day. [LIBOR] is a benchmark giving an indication of the average rate at which a leading bank can obtain unsecured funding . . . for a given period, in a given currency.

The Basics, BBA LIBOR, http://bbalibor.bladonmore.com/bbalibor-explained/thebasics (last visited Mar. 16, 2012).

${ }^{11}$ Typically, the periodic payments are netted against each other, with the party owing the higher amount paying the other party the difference between the two amounts.

${ }^{12}$ The borrower's total payments would be $\$ 100,000-\$ 40,000$ in interest to the lender and a $\$ 60,000$ fixed rate payment to the swap counterparty. Offsetting those payments would be a $\$ 40,000$ floating rate payment from the counterparty. 
If LIBOR averages eight percent, the borrower's net financing cost is the same.

A swap is a type of derivative, which means that it derives its value from some other asset. ${ }^{14}$ Before the CFMA was enacted, the extent to which swaps and other derivatives were subject to federal securities laws was uncertain. The CFMA attempted to eliminate this uncertainty with respect to certain over-the-counter derivatives ${ }^{15}$-those that are both between sophisticated parties and subject to individual negotiation-by excluding them from the definition of "security" for purposes of the Securities Act and the Exchange Act and thereby making the onerous registration and information reporting requirements of those laws inapplicable to them. ${ }^{16}$ At the same time, however, the CFMA made a specific type or category of over-the-counter derivatives-security-based swap agreements-subject to existing antifraud provisions of the Securities Act and the Exchange Act. ${ }^{17}$

The CFMA defined the term "security-based swap agreement" as "a swap agreement... of which a material term is based on the price, yield, value, or volatility of any security or any group or index of securities, or any interest therein." ${ }^{18}$ Since the CFMA was enacted, very few courts have interpreted the term, and it was not until 2008 that the Securities and Exchange Commission (SEC) brought its first antifraud enforcement action with respect to a security-based swap agreement. $^{19}$ In SEC v. Langford, the SEC alleged that the former

13 The borrower's total payments would be $\$ 140,000-\$ 80,000$ in interest to the lender and a $\$ 60,000$ fixed rate payment to the swap counterparty. Offsetting those payments would be an $\$ 80,000$ floating rate payment from the counterparty.

${ }_{14}$ See Romano, supra note 6, at 2 (noting that a derivative's value is based on another asset); Over-The-Counter Derivatives: Modernizing Oversight to Increase Transparency and Reduce Risks: Hearings Before the Subcomm. on Securities, Insurance, and Investment of the S. Comm. on Banking, Housing, and Urban Affairs, 110th Cong. 45 (2009) [hereinafter Schapiro Testimony] (statement of Hon. Mary L. Schapiro, Chairman, U.S. Sec. \& Exch. Comm'n), available

http://www.sec.gov/news/testimony/2009/ts062209mls.htm (indicating that a derivative is based on the value of a "reference" asset or event).

${ }^{15}$ An over-the-counter derivative is one that "is not traded on a regulated exchange." Schapiro Testimony, supra note 14, at 45.

${ }^{16}$ CFMA, Pub. L. 106-554, $§ \S 302$ (a), 303(a), 114 Stat. 2763, 2763A-451 to 2763A453 (codified at 15 U.S.C. $\$ \S 77 \mathrm{~b}-1,78 \mathrm{c}-1$ (2006)).

${ }_{17} I d . \S \S 302(\mathrm{~b}), 303(\mathrm{~d}), 114$ Stat. at $2763 \mathrm{~A}-452,2763 \mathrm{~A}-454(\operatorname{codified}$ at 15 U.S.C. $\S \S 77 q(a), 78 j(b)(2006))$.

${ }_{18}$ Id. $\S 301(\mathrm{a}), 114$ Stat. at 2763A-451 (codified at 15 U.S.C. $§ 78 \mathrm{c}$ note) (adding Gramm-Leach-Bliley Act section 206B), repealed by Dodd-Frank Act, Pub. L. No. 111203, § 762(a), 124 Stat. 1376, 1759 (2010)).

${ }_{19}$ Litigation Release No. 20545, 2008 WL 1902075 (Apr. 30, 2008) [hereinafter Langford Release] (describing the initiation of the Langford enforcement action). 
president of the Jefferson County, Alabama, commission and two of his friends, one a broker-dealer and one a lobbyist, violated Securities Act section 17(a) and Exchange Act section 10(b) and Rule 10b-5 in connection with interest rate swaps (valued at approximately $\$ 3.5$ billion in total) entered into with respect to various series of bonds issued by Jefferson County. ${ }^{20}$ In 2009, the SEC brought a related enforcement action against two managing directors of J.P. Morgan Securities, Inc. In SEC v. LeCroy, the SEC alleged that the J.P. Morgan managing directors violated Securities Act section 17(a) and Exchange Act section 10(b) and Rule 10b-5 with respect to three of the Jefferson County interest rate swaps (valued at approximately $\$ 2$ billion in total) at issue in Langford. ${ }^{21}$ Langford and LeCroy bring to the fore the question of how far the term "security-based swap agreement" extends and, more specifically, whether it is so broad that it may include a simple interest rate swap.

The over-the-counter derivatives market is enormous. Since December 2008, the market value of over-the-counter derivative contracts has exceeded $\$ 20$ trillion. ${ }^{22}$ During that time, the market value of interest rate swaps alone has exceeded $\$ 12.5$ trillion. $^{23}$ Enacted in response to the financial crisis that began at the end of the last decade, Dodd-Frank brings sweeping regulation to this huge segment of the economy that the CFMA largely left unregulated. The reform Act divides the over-the-counter derivatives market into two segments, putting the SEC in charge of one and the Commodity Futures Trading Commission (CFTC) in charge of the other. ${ }^{24}$ The category over which the CFTC has general jurisdiction includes security-based swap agreements, though the term is more narrowly defined. The SEC, however, continues to have the same antifraud jurisdiction over security-based swap agreements that it had previously. ${ }^{25}$ Therefore, the interpretation of the term remains important in defining the reach of the federal securities antifraud provisions.

\footnotetext{
${ }^{20}$ Complaint II I 1-5, 11-12, SEC v. Langford, No. CV-08-B-0761-S (N.D. Ala. Apr. 30, 2008) [hereinafter Langford Complaint], available at http:/ / www.sec.gov/litigation/complaints/2008/comp20545.pdf.

${ }^{21}$ Complaint II 1-14, SEC v. LeCroy, No. CV-09-B-2238-S (N.D. Ala. Nov. 4, 2009) [hereinafter LeCroy Complaint], available at http://www.sec.gov/litigation/complaints/2009/comp21280.pdf.

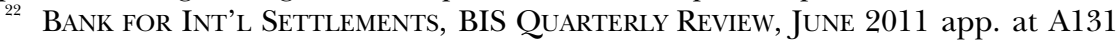
tbl.19 (2011) (on file with the Seton Hall Law Review).

${ }^{23} \mathrm{Id}$.

${ }^{24}$ See infra Part IV (describing the jurisdiction of the SEC and the CFTC under Dodd-Frank).

${ }^{25}$ See infra Part IV (discussing the effect of Dodd-Frank).
} 
This Article examines the historical interpretation of the term "security-based swap agreement," its application in Langford and LeCroy, and the continuing viability of applying antifraud provisions of the Securities Act and the Exchange Act to security-based swap agreements post-Dodd-Frank. It concludes that Congress should eliminate application of antifraud provisions in the federal securities laws to security-based swap agreements because continued application is unnecessary and undesirable after Dodd-Frank.

Part II of this Article discusses the extent to which the securities laws applied to swaps prior to Dodd-Frank and includes a review and critique of the handful of opinions that have considered the scope of the term "security-based swap agreement" as defined before DoddFrank. Part III considers whether the interest rate swaps at issue in Langford and LeCroy were security-based swap agreements under the pre-Dodd-Frank definition. It offers a reasonable argument that they were based on the statutory text, but suggests that such a result makes little sense from a policy perspective. Part IV describes generally the jurisdictional division between the SEC and the CFTC under DoddFrank and how security-based swap agreements fit within the new regime. Part V explores reasons to do away with the "security-based swap agreement" concept in the federal securities laws while considering the possible benefits of retaining it. Finally, Part VI concludes that Congress should eliminate the "security-based swap agreement" concept from the Securities Act and the Exchange Act because the applicable provisions went largely unused pre-Dodd-Frank and likely will be even more inconsequential post-reform, an appropriate allocation of securities antifraud jurisdiction can be achieved without the term, the term has been poorly interpreted and is overly broad, and the term results in redundancy and confusion in the new regulatory scheme.

\section{Treatment OF SWAPS Under the SECURITIES LAWS PRIOR TO DODD-FRANK}

\section{A. Commodity Futures Modernization Act of 2000}

Section 17(a) of the Securities Act and section 10(b) of the Exchange Act are two of the primary antifraud provisions of the federal securities laws. Rule 10b-5 was promulgated under section 10(b) in 1942 and, since then, has served as a "powerful antifraud weapon." 26 Securities Act section 17(a) prohibits fraud "in the offer or sale of any

${ }^{26}$ Thomas Lee Hazen, The Law of Securities Regulation $\$ 12.3$ [2], at 442 (2009). 
securities," ${ }^{27}$ and Exchange Act section 10(b) and Rule 10b-5 prohibit fraud "in connection with the purchase or sale of any security." to the CFMA, if a transaction did not involve a security, it was not subject to section 17 (a), section 10(b), or Rule 10b-5.

Until the CFMA was enacted, whether a swap could be a security was an open question. A single 1996 opinion by the United States District Court for the Southern District of Ohio had concluded that two specific interest rate swaps were not securities, ${ }^{29}$ but not surpris-

$27 \quad 15$ U.S.C. $\$ 77 q(a)$ (2006) (emphasis added). ed).

${ }^{28} I d . \S 78 \mathrm{j}(\mathrm{b})$ (emphasis added); 17 C.F.R. $§ 240.10 \mathrm{~b}-5$ (c) (2011) (emphasis add-

${ }^{29}$ Proctor \& Gamble Co. v. Bankers Trust Co., 925 F. Supp. 1270, 1283 (S.D. Ohio 1996). Both swaps at issue in Proctor $\mathcal{E}^{2}$ Gamble were leveraged interest rate swaps. Under one of the swaps, which the district court referred to as the " $5 \mathrm{~s} / 30 \mathrm{~s}$ swap," Bankers Trust agreed to pay a fixed rate equal to $5.30 \%$, and in return, Proctor \& Gamble agreed to pay a floating rate equal to the prevailing commercial paper rate minus seventy-five basis points plus, after the first six months, a spread determined in reference to the yields and prices of certain treasury securities. Id. at 1276. In concluding that the $5 \mathrm{~s} / 30$ s swap was not a security under the Securities Act or the Exchange Act, the court specifically determined that it (i) was not an investment contract because it did not involve a "common enterprise" or the entrepreneurial efforts of others as required by SEC v. Howey, 328 U.S. 293 (1946), and was not an "instrument commonly known as a security" for the same reasons; (ii) was not a note or evidence of indebtedness because there was no exchange of principal and the facts with respect to the swap did not meet the requirements of the "family resemblance" test set out by the Supreme Court in Reves v. Ernst $\mathcal{E}$ Young, 494 U.S. 56 (1990); and (iii) was not an option because, even though it was based on a security, it did not give either party the right to take possession of a security. Proctor E Gamble, 925 F. Supp. at 1278-80, 1282-83, 1293

In reaching its decision, the Proctor $\mathcal{E}$ Gamble court noted that it was not bound by the SEC's decision in two related administrative proceedings that a "Treasury-Linked Swap," a swap quite similar to the 5s/30s swap in Proctor E Gamble, was a security. Id. at 1281 (citing In re Vazquez, Securities Act Release No. 33-7269, Exchange Act Release No. 34-36906, 1996 WL 86528 (Feb. 29, 1996); In re BT Sec. Corp., Securities Act Release No. 33-7124, Exchange Act Release No. 34-35136, 1994 WL 710743 (Dec. 22, 1994)). In BT Securities and Vazquez, the SEC observed that the "Treasury-Linked Swap" was not truly a swap, but in substance was a cash-settled option based on the price and yields of treasury securities. Vazquez, 1996 WL 86528, at *4 n.4; BT Securities, 1994 WL 710743, at $* 9$ n.6. According to the SEC, as an option based on securities, the swap was also a security. BT Securities, 1994 WL 710743, at *9 n. 6.

In 2002, the United States Court of Appeals for the Second Circuit concluded that Proctor $\mathcal{E}$ Gamble was incorrect in finding that, for an option to be a security, the instrument must contain a right to exercise and take possession of a security. Caiola v. Citibank, N.A., 295 F.3d 312, 326 (2d Cir. 2002). To the contrary, the Second Circuit observed that the definition of "security" under the Exchange Act includes a cash-settled option on a security. Id. at 325. The Caiola opinion, which determined that a cash-settled option on a security is itself a security, does not necessarily indicate that the 5s/30s swap in Proctor $\mathcal{E}$ Gamble was also a security. The Second Circuit in Caiola observed that the definition of "security" in Exchange Act section 3(a) (10) does not "distinguish between options documented as swaps as opposed to options 
ingly, that decision alone could not quell the uncertainty surrounding the treatment of swaps under the federal securities laws. Viewing the uncertainty as detrimental to the marketplace, ${ }^{30}$ Congress enacted the CFMA in 2000.

The CFMA resolved the uncertainty through amendments to the Gramm-Leach-Bliley Act ${ }^{31}$ (GLBA), the Securities Act, and the Exchange Act. The CFMA amended the GLBA to add section 206A, which defined the term "swap agreement" broadly to include, among other things,

any agreement, contract, or transaction between eligible contract participants..., the material terms of which (other than price and quantity) are subject to individual negotiation, and that... provides on an executory basis for the exchange, on a fixed or contingent basis, of one or more payments based on the value or level of one or more interest or other rates, currencies, commodities, securities, instruments of indebtedness, indices, quantitative measures, or other financial or economic interests or property of any kind, or any interest therein or based on the value thereof, and that transfers, as between the parties to the transaction, in whole or in part, the financial risk associated with a future change in any such value or level without also conveying a current or future direct or indirect ownership interest in an asset ... or liability that incorporates the financial risk so transferred, including any such agreement, contract, or transaction commonly known as an interest rate swap, including a rate floor, rate cap, rate collar, cross-currency rate swap, basis swap, currency swap, equity index swap, equity swap, debt index swap, debt swap, credit spread,

documented in some other fashion," but indicated that it was not addressing whether an "interest rate swap" with "option-like features" is a security. Id. at 326.

${ }^{30}$ One of the goals of the CFMA was to provide certainty that swap agreements generally were not subject to securities laws or commodities laws. See CFMA, Pub. L. No. 106-554, § 2(6), 114 Stat. 2763A-365, 2763A-366 (codified at 7 U.S.C. $§ 1$ note (2006)) (stating that one of the purposes of the Act was the "reduc[tion of] systemic risk by enhancing legal certainty in the markets for certain futures and derivatives transactions"); see also 146 CONG. REC. 27,176 (2000) (statement of Sen. Gramm) ("It is important to note that nothing in the title should be read to imply that swap agreements are either securities or futures contracts."); 146 CONG. REC. 27,077 (2000) (statement of Rep. Dingell) ("[One of t] he fundamental purposes of [the CFMA is ] . . to provide legal certainty for the over-the counter derivatives market."). Congress placed the definition of "swap agreement" in the Gramm-Leach-Bliley Act because it is "a neutral statute . . . that is not specifically part of a banking, securities, or commodities law.” 146 CONG. REc. 27, 176 (2000) (statement of Sen. Gramm).

31 Gramm-Leach-Bliley Act, 15 U.S.C. $\$ 78$ c note (2006). 
credit default swap, credit swap, weather swap, or commodity swap ....

The CFMA then divided swap agreements into two types-"securitybased swap agreements" and "non-security-based swap agreements"through the addition of sections $206 \mathrm{~B}$ and 206C to the GLBA. The term "security-based swap agreement" was defined as "a swap agreement ... of which a material term is based on the price, yield, value, or volatility of any security or any group or index of securities, or any interest therein;" "33 the term "non-security-based swap agreement" meant everything else. ${ }^{34}$ Finally, the CFMA added Section 2A to the Securities Act and section $3 \mathrm{~A}$ to the Exchange Act, both of which provided that the definition of "security" included neither type of swap agreement.

The combined effect of the CFMA amendments to the GLBA, the Securities Act, and the Exchange Act was to remove all swap agreements from the registration and reporting requirements of the Securities Act and the Exchange Act. ${ }^{36}$ The CFMA, however, did not

${ }^{32}$ CFMA $\$ 301(\mathrm{a}), 114$ Stat. at $2763 \mathrm{~A}-449$ to $2763 \mathrm{~A}-450$ (codified at 15 U.S.C. $\S$ 78c note (2006)) (adding Gramm-Leach-Bliley Act section 206A). The CFMA housed the definition of "eligible contract participant" in section 1a(12) of the Commodity Exchange Act. Id. § 101, 114 Stat. at 2763A-368 to 2763A-371 (codified at 7 U.S.C. $§ 1 \mathrm{a}(12)(2006))$. Under Section 1a(12), eligible contract participants include sophisticated persons and entities such as financial institutions; regulated insurance companies; regulated investment companies; certain commodity pools; corporations, partnerships, proprietorships, organizations, trusts, and other entities that have a minimum of total assets; certain employee benefit plans; governmental entities and political subdivisions, instrumentalities, agencies, and departments thereof that own and invest on a discretionary basis a minimum amount of investments; certain brokers and dealers; and individuals with a minimum of total assets. Id.

33 CFMA § 301(a), 114 Stat. at 2763A-451 (codified at 15 U.S.C. § 78c note (2006)) (adding Gramm-Leach-Bliley Act section 206B), repealed by Dodd-Frank Act, Pub. L. No. 111-203, § 762(a), 124 Stat. at 1376, 1759 (2010).

${ }^{34}$ See id. (adding Gramm-Leach-Bliley Act $\$ 206 \mathrm{C}$ ), repealed by Dodd-Frank Act $\S$ 762(a), 124 Stat. at 1376, 1759 ("[T] he term 'nonsecurity-based swap agreement' means any swap agreement . . . that is not a security-based swap agreement.").

${ }^{35}$ See 15 U.S.C. $\$ 77 \mathrm{~b}-1$ (b) (1) (2006) ("[T] he definition of 'security'. . does not include any security-based swap agreement.”); id. § 78c-1(b)(1) (same); id. § 77b1(b) (1) ( "[T] he definition of 'security' . . does not include any non-security-based swap agreement”); $i d$. $\$ 78 \mathrm{c}-1$ (a) (same).

${ }^{36}$ The CFMA amendments to the Securities Act and the Exchange Act did not necessarily establish that all swaps were not securities. The definition of "swap agreement" in GLBA section 206A includes several exceptions. See Gramm-LeachBliley Act $\$ 206 \mathrm{~A}(\mathrm{~b}), 15$ U.S.C. \$ 78c note (2006) (listing exclusions from the term "swap agreement"). Moreover, if a party to a swap was not an eligible contract participant or the material terms were not subject to individual negotiation, the swap was not considered a swap agreement under GLBA, and therefore Securities Act section 2A and Exchange Act section 3A would not exclude the swap from the definition of se- 
exclude swap agreements so broadly from the reach of the antifraud provisions of those laws. Although Securities Act $\S 2 \mathrm{~A}(\mathrm{~b})(2)$ and (3) and Exchange Act $\S 3 \mathrm{~A}(\mathrm{~b})(2)$ and (3) generally prohibited the SEC from taking "prophylactic measures against fraud, manipulation, or insider trading with respect to any security-based swap agreements," the CFMA amended the antifraud provisions in section 17(a) of the Securities Act and section 10(b) of the Exchange Act to include security-based swap agreements within their scope.

\section{B. Opinions Addressing Security-Based Swap Agreements}

The pre-Dodd-Frank definition of "security-based swap agreement" consists of five components. ${ }^{38}$ For an agreement, contract, or transaction to be a security-based swap agreement:

- the agreement, contract, or transaction must be a swap agreement;

- the swap agreement must have a term that relates to a price, yield, value, or volatility;

- the term must be based on the price, yield, value, or volatility;

- the price, yield, value, or volatility must be of a security, $a$ group or index of securities, or an interest in a security or group or index of securities; and

- $\quad$ the term must be material.

curity under Securities Act section 2(a) (1) and Exchange Act section 3(a)(10). See $\S$ 206A(a).

${ }^{37}$ CFMA $\S \S 302(b), 303(d), 114$ Stat. at 2763A-452, 2763A-454 (codified at 15 U.S.C. $\$ \S 77 q(a), 78 j(2006)$ ). The CFMA also made security-based swap agreements subject to the antimanipulation provisions of the Exchange Act sections 9(a), $15(\mathrm{c})(1), 16(\mathrm{a})$ and $(\mathrm{b}), 20(\mathrm{~d})$, and 21A(a) (1). Id. § 303(b)-(c), (e)-(k), 114 Stat. at $2763 \mathrm{~A}-453$ to $2763 \mathrm{~A}-454,2763 \mathrm{~A}-454$ to $2763 \mathrm{~A}-456$ (codified at 15 U.S.C. $\$ \$ 78 \mathrm{i}, 78 \mathrm{o}$, 78p, 78t, 78u-1 (2006)). It amended Exchange Act section 10 (b) to provide that security-based swap agreements were subject to rules under section $10(\mathrm{~b})$, including Rule 10b-5, and to judicial precedents under Securities Act section 17(a) and Exchange Act sections 9(a), 10(b), 15(c)(1), 16(a) and (b), 20(d), and 21A(a)(1). Id. $\S 302$ (codified at 15 U.S.C. $\$ 78 \mathrm{j}(2006)$ ). No specific amendment to the text of Rule 10b-5 therefore was required, and the SEC, accordingly, has never amended Rule 10b-5 to reference security-based swap agreements. See 17 C.F.R. § 240.10b-5 (2012).

${ }^{38}$ The post-Dodd-Frank definition includes the same five components, but excludes any "security-based swap" from the definition. See infra notes 199-202 and accompanying text (describing how Dodd-Frank amended the definition of "securitybased swap agreement"). The term "security-based swap" is a new term added by Dodd-Frank. See infra note 196 and accompanying text (discussing the term "security-based swap"). 
[Vol. 42:953

Since the CFMA was enacted, very few opinions have been issued in cases involving swaps described as security-based swap agreements and only one of those opinions - the 2010 opinion of the United States District Court for the Southern District of New York in SEC v. Rorech $^{40}$ - has given studied attention to the definition of the term. Rorech offered important guidance as to two components of the definition-when a term is based on price, yield, value, or volatility and when a term is material.

Unfortunately, opinions in other cases involving security-based swap agreements have done little to develop the contours of the definition. These other opinions fit into one of two categories. In one category are the opinions in St. Matthew's Baptist Church v. Wachovia Bank, National Ass' $n^{41}$ and School District of the City of Erie v. J.P. Morgan Chase Bank, ${ }^{42}$ which summarily excluded LIBOR-based interest rate swaps from the definition merely because LIBOR is not determined in reference to any security. In the other category are the opinions in Caiola v. Citibank, N.A., which merely made conclusory statements that the swaps at issue were security-based swap agreements, ${ }^{43}$ and the opinions in Elliott Assocs. v. Porsche Automobil Holding SE, SEC v. Wyly, and SEC v. Goldman Sachs Eै Co., ${ }^{46}$ which did not address whether the swaps involved met the definition. ${ }^{47}$

\section{Rorech}

In Rorech, the SEC alleged that Jon-Paul Rorech and Renato Negrin had engaged in illegal insider trading with respect to two credit default swaps (CDSs). ${ }^{48}$ Each of the $\mathrm{CDSs}^{49}$ referenced VNU

39 See Gramm-Leach-Bliley Act $\S 206 \mathrm{~B}, 15$ U.S.C. $§ 78$ c note (2006), repealed by Dodd-Frank Act, Pub. L. No. 111-203, § 762(a), 124 Stat. at 1376, 1759 (2010) (amending 15 U.S.C. $§ 78 \mathrm{c}$ note) (defining the term "security-based swap agreement").

40720 F. Supp. 2d 367 (S.D.N.Y. 2010).

${ }^{41}$ No. Civ.A. 04-4540(FLW), 2005 WL 1199045 (D.N.J. May 18, 2005).

${ }^{42}$ No. 08 CV 07688LAP, 08 CV 07982, 2009 WL 234128 (S.D.N.Y. Jan. 30, 2009).

43295 F.3d 312, 316 (2d Cir. 2002); Caiola v. Citibank, N.A, 137 F. Supp. 2d 362 (S.D.N.Y. 2001), rev'd 295 F.3d 312.

${ }^{44} 759$ F. Supp. 2d 469 (2010).

45 No. 10 Civ. 5760 (SAS), 2011 WL 1226381 (S.D.N.Y. Mar. 31, 2011).

${ }^{46}$ No. 10 Civ. 3229(BSJ) (MHD), 2011 WL 2305988 (S.D.N.Y. June 10, 2011).

${ }^{47}$ The opinions that have been issued in LeCroy and Langford, likewise, do not address whether the swaps at issue meet the definition of "security-based swap agreement." Those opinions are described in Part III infra.

${ }^{48}$ SEC v. Rorech, 720 F. Supp. 2d 367, 370, 404-05 (S.D.N.Y. 2010).

49 The District Court in Rorech explained how a typical CDS works: 
N.V., a Dutch company, and a particular VNU bond. ${ }^{50}$ Each also had a notional amount of $\$ 10$ million and required the buyer to pay a price, or "spread," of 383 basis points $(3.83 \%)$ on a quarterly basis. The swaps further provided that, upon the occurrence of certain credit events with respect to VNU, the swap seller would pay the notional amount to the swap buyer and the swap buyer would deliver the referenced VNU bond to the swap seller.

The SEC argued that the CDSs were security-based swap agreements subject to the antifraud provisions of Exchange Act section 10 (b) and Rule 10b-5 because their price was based on the price, yield, value, or volatility of VNU bonds, which were securities. ${ }^{53}$ The defendants, though willing to acknowledge that the price of the swaps might be related to the price, yield, value, or volatility of the VNU bonds, denied that the price was based on the price, yield, value or volatility of the VNU bonds. ${ }^{54}$ The defendants argued that the term "based on" requires a "direct, or exclusive dependence" and that factors unrelated to the VNU bonds were incorporated in pricing the swaps-factors such as general market conditions and the market's determination of the risk that VNU would not meet its obligations. ${ }^{55}$ The defendants also argued that the material terms of the CDSs were not "based on" the price, yield, value, or volatility of the VNU bonds because the swap contracts themselves did not "explicitly refer to the

While there are different types of CDSs, the CDSs that are at issue in this case are contracts that provide protection against the credit risk of a particular company. The seller of a CDS agrees to pay the buyer a specific sum of money, called the notional amount, if a credit event, such as bankruptcy, occurs in the referenced company. If a credit event occurs, the buyer generally must provide to the seller any of certain debt instruments that are deliverable pursuant to the CDS contract. In exchange for this risk protection from the CDS-seller, the CDS-buyer agrees to make periodic premium payments during the course of the contract. The CDS-buyer can use the CDS to provide protection, like insurance, against the possibility that the debt instruments the buyer holds will seriously deteriorate in value because of a credit event in the referenced company. The CDS-buyer could also buy the CDS without owning the underlying referenced security, a "naked CDS," in the expectation that it would increase in value based on any one of a number of factors including the likelihood that a credit event will occur in the referenced company. Id. at $370-71$.

${ }^{50}$ Id. at $371,387$.

${ }^{51} \quad I d$. at 387.

${ }^{52} I d$. at $370-71,387$.

${ }_{53} I d$. at 405 .

${ }^{54}$ Rorech, 720 F. Supp. 2d at 405

${ }^{55}$ Id. at 405 . 
price or value of any security." ${ }^{56}$ The defendants observed that the price of each CDS was simply stated in basis points.

Although the district court ultimately entered judgment in favor of the defendants because the SEC failed to offer sufficient evidence to support insider trading, ${ }^{58}$ the court agreed with the SEC that the swaps were security-based swap agreements. ${ }^{59}$ The court concluded that, to be "based on" the price, yield, value, or volatility of the VNU bonds, the price of the VNU swaps need not have been exclusively connected to one of those elements. ${ }^{60}$ Noting that the GLBA did not define the term "based on," the court applied the ordinary meaning of the term, stating that "it means to use as the fundamental part or ingredient of, or principal component of, something.," According to the court, applying the ordinary meaning was appropriate in light of the term's context within the GLBA and its place within the securities antifraud regime. ${ }^{62}$ The court asserted, moreover, that the legislative history of the GLBA indicated that Congress intended to sweep broadly to bring "novel financial instruments" within the scope of the Exchange Act's antifraud provisions and that requiring an explicit reference to a security in a swap agreement would be inconsistent with that intent.

Looking to the ordinary meaning of "based on," the district court concluded that the CDSs at issue in the case were security-based swap agreements for two reasons. First, the spread (or yield), price, and value of VNU bonds deliverable under the CDSs were a "fundamental" consideration of the buyer in evaluating the price to pay for the swaps. ${ }^{64}$ Second, the documents governing each CDS included a provision under which cash settlement of the swap was to be calculated using the price of VNU obligations deliverable under the swap. ${ }^{65}$ The court determined that this provision was material because the amount to be delivered at settlement "was plainly part of, if not all of,

${ }^{56} I d$.

${ }^{57} I d$.

${ }_{58} I d$. at $415-17$.

${ }^{59} \quad I d$. at 408.

${ }^{60}$ Rorech, 720 F. Supp. 2d at 405.

${ }^{61}$ Id.

${ }^{62} I d$. at 406.

${ }^{63} I d$. at 406-07.

${ }^{64}$ Id. at 407.

${ }^{65} \mathrm{Id}$. at 408 . 
the consideration for which the CDS-buyer agreed to make premium payments." ${ }^{66}$

Rorech provides valuable guidance as to how to determine whether a term is material and what it means for a term to be based on price, yield, value, or volatility. Regarding materiality, Rorech simply indicates that " $[\mathrm{t}]$ he material terms of a contract are those that must be sufficiently definite to allow the contract to be enforceable. Examples... include subject matter, price, payment terms, quantity, timing, compensation, and duration." ${ }^{67}$ With respect to the meaning of "based on," Rorech makes two significant points. First, for a term to be "based on" price, yield, value, or volatility means only that the price, yield, value, or volatility must be a principal or fundamental part of the term. ${ }^{68}$ A direct or exclusive relationship is not required. ${ }^{69}$ Second, a swap agreement itself need not specifically reference price, yield, value, or volatility. It is sufficient that price, yield, value, or volatility be used in evaluating the relevant term.

Rorech's parameters for the term "based on" are reasonable in light of the legislative history of the CFMA. As the opinion noted, the legislative history, albeit slim, ${ }^{71}$ suggests that Congress intended the term "security-based swap agreement" to be flexible enough to address new types of instruments. ${ }^{72}$ A narrow interpretation of "based on" would deprive it of that flexibility.

${ }^{66}$ Rorech, 720 F. Supp. 2d at 408.

${ }^{67} \quad I d$.

${ }^{68} \quad I d$. at 407.

${ }^{69}$ See id. at 407 (noting that requiring "a direct, explicit relationship . . . would allow traders to escape the ambit of section $10(\mathrm{~b})$ and Rule 10b-5 through clever drafting").

${ }^{70}$ See id. at 407 (noting that, in deciding whether to purchase the CDSs at issue in Rorech, the swap buyer considered the yield, price, and value of the referenced bonds).

${ }^{71}$ Caiola v. Citibank, N.A. 137 F. Supp. 2d 362, 371 (S.D.N.Y. 2001) ("The legislative history of the CFMA concerning security-based swap agreements is sparse ....").

72 See, e.g., 146 Cong. REc. 27,309 (2000) (statement of Sen. Sarbanes) ("Title III [of the CFMA] applies anti-fraud and anti-manipulation provisions of the Federal securities laws to securities-based swap agreements .... This will enhance protection for investors and for the financial markets, and will permit the SEC to respond as necessary to developments in these markets."); 146 Cong. REC. 27,078 (2000) (statement of Rep. Dingell) ("One of the most important provisions of the [CFMA] . . gives the SEC antifraud authority over securities-based swap agreements . . . This permits the SEC to use its tested methods to enhance the protection in [the swap] markets and to respond as necessary to developments in the future."); see also Rorech, 720 F. Supp. 2d at 406 ("Administration officials and congressional members expressed support for making it clear that the SEC's traditional anti-fraud and insider trading enforcement authority applied to novel financial instruments."). 
Although Rorech's ultimate explanation of the meaning of "based on" seems correct, the court's discussion of how the GLBA statutory scheme supports its conclusion that the CDSs at issue in the case met the "based on" requirement is peculiar. In reaching its conclusion, the court reasoned that Congress must have intended the CDSs at issue in the case to be subject to Exchange Act section 10(b) and Rule 10b-5 because Congress had included in the broad definition of "swap agreement" both interest rate swaps, "which clearly are not "security based swap agreements," and CDSs. ${ }^{73}$ For that and other reasons, according to the court, it was appropriate to conclude that the CDSs at issue were "based on" the price, yield, value, or volatility of the VNU bonds and therefore were security-based swap agreements. ${ }^{74}$

The court's statement that interest rate swaps "clearly" are not security-based swap agreements suggests that the court blindly followed, and extended to all interest rate swaps, the conclusion reached in both St. Matthew's and School District of Erie that LIBORbased interest rate swaps are not security-based swap agreements. ${ }^{75}$ A plain interpretation of the GLBA belies the clarity that Rorech declared. Under GLBA section 206A, the definition of "swap agreement" includes interest rate swaps. ${ }^{76}$ The definition of "security-based swap agreement" in GLBA section 206B simply is "a swap agreement (as defined in section 206A of [GLBA]) of which a material term is based on the price, yield, value, or volatility of any security or any group of index of securities, or any interest therein." ${ }^{77}$ Taking these two definitions together, then, an interest rate swap "of which a material term is based on the price, yield, value, or volatility of any security or any group of index of securities, or any interest therein" is a security-based swap agreement. If Congress had intended to exclude interest rate swaps from the definition, it could have done so explicitly in the definition of "security-based swap agreement." Congress did not.

73 Rorech, 720 F. Supp. 2d at 406.

See id. at 408.

75 See id. at 406 (citing Sch. Dist. of Erie v. J.P. Morgan Chase Bank, No. 08 CV 07688, 08 CV 07982, 2009 WL 234128, at *1 (S.D.N.Y. Jan. 30, 2009); St. Matthew's Baptist Church v. Wachovia Bank Nat'l Ass'n, No. Civ.A. 04-4540(FLW), 2005 WL 1199045 , at *12-13 (D.N.J. May 18, 2005)).

${ }^{76}$ Gramm-Leach-Bliley Act $\$ 206 \mathrm{~A}(\mathrm{a})$ (3), 15 U.S.C. $\$ 78$ c note (2006).

${ }_{77}$ Id. $\$ 206 \mathrm{~B}$, repealed by Dodd-Frank Act, Pub. L. No. 111-203, § 762(a), 124 Stat. 1376,1759 (2010). 


\section{St. Matthew's and School District of Erie}

About five years before Rorech, the United States District Court for the District of New Jersey in St. Matthew's Baptist Church v. Wachovia Bank National Ass'n considered the substance of the term "security-based swap agreement" in connection with a private cause of action under Exchange Act section 10(b) and Rule 10b-5. ${ }^{78}$ St. Matthew's Baptist Church alleged that Wachovia had violated Exchange Act section $10(\mathrm{~b})$ and Rule $10 \mathrm{~b}-5$ with respect to a floating-to-fixed interest rate swap the church had entered into with Wachovia. ${ }^{79}$ The church had obtained an approximately $\$ 5$ million loan from Wachovia and delivered to Wachovia a note under which the church agreed to pay interest at a rate equal to one-month LIBOR plus $1.50 \%{ }^{80}$ Approximately two months before, in anticipation of the loan, the parties had entered into an interest rate swap with a notional amount equal to the principal amount of the loan. ${ }^{81}$ Under the swap, the church agreed to make payments to Wachovia based on a fixed rate equal to $9.13 \%$, and Wachovia agreed to make payments to the church based on a floating rate equal to LIBOR plus $1.50 \%{ }^{82}$

The church argued that the swap was a security-based swap agreement subject to the antifraud provisions of Exchange Act section $10(\mathrm{~b})$ and Rule 10b-5 because the floating rate under the swap was based on LIBOR. ${ }^{83}$ The district court disagreed, taking judicial notice of the British Bankers' Association's explanation that LIBOR is an interest rate and concluding "therefore [that LIBOR is] not an index based on the "price, yield, value, or volatility of any security or

${ }^{78}$ St. Matthew's, 2005 WL 1199045 (D.N.J. May 18, 2005). Although Exchange Act section 10 (b) does not expressly provide for a private cause of action and nothing indicates that Congress intended a private cause of action, the United States Supreme Court, following a long line of cases from the lower courts, determined that a private cause of action indeed exists. Blue Chip Stamps v. Manor Drug Stores, 421 U.S. 723, 729-30 (1975). The general consensus is that no similar private cause of action exists under Securities Act section 17(a). See, e.g., Koehler v. Bank of Berm. (N.Y.) Ltd., 209 F.3d 130, 136 (2d Cir. 2000) (citing Finkel v. Stratton Corp., 962 F.2d 169, 174-75 (2d Cir. 1992) (indicating that no private right of action exists under section 17(a))); Maldonado v. Dominguez, 137 F.3d 1, 7 (1st Cir. 1998) ("In recent years, every circuit to have addressed the issue has refused to recognize a private right of action .....").

79 St. Matthew's, 2005 WL 1199045, at *2.

${ }^{80} I d$. The opinion incorrectly states that the interest rate on the note was onemonth LIBOR plus $150 \%$. Id. The actual rate was one-month LIBOR plus 150 basis points or $1.5 \%$. Complaint at 25, St. Matthew's Baptist Church v. Wachovia Bank Nat'l Ass'n, No. Civ.A. 04-4540(FLW),(D.N.J. May 18, 2005).

${ }^{81}$ St. Matthew's, 2005 WL 1199045, at*1.

${ }^{82} I d$.

${ }^{83} I d$. at $* 13$. 
any group or index of securities." ${ }^{84}$ As a result, according to the court, the swap was not a security-based swap agreement.

The court in St. Matthew's reached the right result, but not necessarily for the right reason. The definition of swap agreement in GLBA section 206A specifically includes interest rate swaps. ${ }^{86}$ For a floating-to-fixed interest rate swap, both the floating rate and the fixed rate are material because each rate represents the "price" paid to receive the other rate. ${ }^{87}$ The floating rate under the swap at issue in St. Matthew's, LIBOR plus $1.50 \%$, was the very same rate as the interest rate in the note; therefore, one easily could conclude that the floating swap rate was based on the interest rate in the note. The interest rate on the note was more than a fundamental part of determining the floating rate-it was the floating rate.

The St. Matthew's court incorrectly suggested that the relevant question in the case was whether LIBOR was an index based on "the price, yield, value, or volatility of any security or any group or index of securities." The definition of security-based swap agreement, however, requires that a material term of the swap agreement be based on "the price, yield, value, or volatility of any security or any group or index of securities or any interest therein." Because the floating and fixed rates under the swap were material terms and because the floating rate was based on the interest rate under the note, the questions that the court should have asked were whether the note was a security and whether the identity of the floating rate and the variable interest rate meant that either the floating rate or the fixed rate was based on the price, yield, value or volatility of an interest in the note. In St. Matthew's, the former question was an easy one. The note was not a security under Reves $v$. Ernst $\mathcal{E}$ Young, $^{88}$ and for that reason alone, the

84 Id.

${ }^{85}$ See id. (dismissing the federal securities claims).

${ }^{86}$ Gramm-Leach-Bliley Act $\$ 206 A(a)(3), 15$ U.S.C. $\$ 78$ c note (2006).

${ }^{87}$ See SEC v. Rorech, 720 F. Supp. 2d 367, 408 (S.D.N.Y. 2010) ("The material terms of a contract are those terms that must be sufficiently definite to allow the contract to be enforceable. Examples . . . include subject matter, price, payment terms, quantity, timing, compensation, and duration.”).

${ }^{88} 494$ U.S. 56 (1990). Although Securities Act section 2(a) (1) and Exchange Act section 3(a) (10) both include "note" in the definition of "security," the United States Supreme Court has determined that not all notes are securities. Id. at 63 . The note in St. Matthew's was issued to refinance a short-term loan for the construction of church facilities. St. Matthew's, 2005 WL 1199045, at*1. Under Reves, the St. Matthew's note would not be a security because it was issued for construction with respect to a church, it was not distributed, the investing public would not expect a note by a church for a bank loan to be a security, and as a large, sophisticated investor, Wachovia was not the type of investor that the securities laws generally seek to protect. 
swap was not a security-based swap agreement. ${ }^{89}$ The court did not need to reach the latter, more difficult, question about which the SEC and the defendants in Langford and LeCroy have disagreed.

About four years after St. Matthew's, the United States District Court for the Southern District of New York in School District of the City of Erie v. J.P. Morgan Chase Bank considered whether a LIBOR-based "swaption" was a security-based swap agreement. ${ }^{90}$ Butler County General Authority had issued bonds for the benefit of the Erie School District (the "School Bonds"). ${ }^{91}$ The School Bonds bore interest at fixed interest rates. ${ }^{92}$ A few years after the School Bonds were issued, interest rates dropped, making it desirable for the school district to refinance the bonds. ${ }^{93}$ Because of the terms of the bonds and limitations under the tax laws, however, the school district could not refinance merely by issuing new bonds and immediately repaying the

See Reves, 494 U.S. at 66-67 (indicating that a note is presumed to be a security and describing when the presumption is rebutted).

${ }^{89}$ The plaintiff in School District of Erie made this point. Sch. Dist. of Erie v. J.P. Morgan Chase Bank, No. 08 CV 07688LAP, 08 CV 07982, 2009 WL 234128, at *1 (S.D.N.Y. Jan. 30, 2009).

${ }^{90} I d$.

$[\mathrm{I}] \mathrm{n}$ a swaption, one party [Party $\mathrm{A}] \ldots$. . has the right, but not the obligation, to enter into .... [a] swap with the other party [Party B] ... at a specified fixed rate and floating rate formula, on a specified date or during a specified period in the future. In exchange for that right, [Party A] will pay an option premium to [Party B] on the trade date.

The Handbook of Municipal Bonds 310 (Sylvan G. Feldstein \& Frank J. Fabozzi, eds., 2008). As explained in the School District of Erie complaint, if Party A is to receive the floating rate under the contract, "[the swaption] is designed to give [Party A] the benefit of the agreed upon [fixed rate] if the market rates are higher . . .; the converse is true if the holder of the swaption receives the fixed rate under the swap agreement." Complaint II 9, Sch. Dist. of Erie v. J.P. Morgan Chase Bank, No. 08 CV 07688-LP (S.D.N.Y. Jan. 30, 2009), 2008 WL 5367780 [hereinafter Erie Complaint].

${ }^{91}$ Erie Complaint, supra note 90, $\mathbb{I} 10$.

${ }^{92}$ See Brief for Plaintiffs, School District of the City of Erie and Butler County General Authority, in Opposition to Defendant's Motion to Dismiss the Complaint Pursuant to Federal Rule of Civil Procedure 12(b) (6) at 6, Sch. Dist. of Erie v. J.P. Morgan Chase Bank, No. 08 CV 07688 (S.D.N.Y. Jan. 30, 2009), 2008 WL 5593915 [hereinafter School District Brief] (indicating that the School Bonds were fixed rate bonds). Although the opinion and pleadings are not clear on this point, the bonds very likely had multiple maturities and different interest rates associated with each maturity.

${ }^{93}$ See Memorandum of Law in Support of Defendant's Motion to Dismiss the Complaint at 5, Sch. Dist. of Erie v. J.P. Morgan Chase Bank, No. 08 CIV 7688LAP (S.D.N.Y. Jan. 30, 2009), 2008 WL 5596124 [hereinafter JP Morgan Motion to Dismiss]. 
old ones. $^{94}$ It could, however, achieve a similar economic result through a "synthetic refunding" accomplished by issuing a fixed-tofloating interest rate swaption. ${ }^{95}$ Accordingly, in exchange for a payment of $\$ 755,000$, the Butler County General Authority, as the school district's agent, issued a swaption to J.P. Morgan Chase Bank ("J.P. Morgan") under which J.P. Morgan had the right at any time between 2011 and 2021 to enter into an interest rate swap with the authority. ${ }^{96}$ If J.P. Morgan exercised its option, the authority would make periodic payments under the swap based on a fixed rate that had been determined in reference to the fixed interest rates on the School Bonds, and J.P. Morgan would make periodic payments based on a floating rate determined in reference to LIBOR. ${ }^{97}$ About five years after the parties entered into the swaption, the school district filed a lawsuit against J.P. Morgan, claiming violations of Exchange Act section 10 (b) and Rule $10 \mathrm{~b}-5 .{ }^{98}$

The District Court dismissed the claims, finding that the swaption did not constitute a security-based swap agreement. ${ }^{99}$ In reaching its decision, the court looked to St. Matthew's, suggesting that the New Jersey District Court had held broadly that "LIBOR based swaps are not security-based [swap agreements]." ${ }^{\text {"100 }}$ The court also cited In re Snell $\mathcal{E}^{2}$ LeCroy, ${ }^{101}$ an SEC administrative proceeding, as "holding ... that even if ... parties enter[] into an interest rate swap agreement at the same time as [an] underlying bond transaction, the two transactions are not a single transaction with a bond component." The court confusingly indicated that, "similarly," the fixed

${ }^{94} I d$. ("[A]pplicable treasury regulations restricted [the school district] from refinancing" the School Bonds immediately).

${ }_{95}$ Id. (indicating that the school district could "benefit immediately" by entering into the swaption). In simple terms, a "synthetic refunding" is a means by which a borrower can achieve the economic benefit of repaying (or providing for the repayment of) outstanding bonds with proceeds from the issuance of new bonds, but without actually taking those steps. The mechanics of, and economics underlying, a synthetic refunding are beyond the scope of this Article. For a simple explanation, see The HANDBoOK OF Municipal Bonds, supra note 90, at 310-11.

${ }^{96}$ Erie Complaint, supra note 90 , II 32.

${ }^{97}$ Id. I 10.

${ }^{98}$ Id. II $34-39$.

${ }^{99}$ Sch. Dist. of Erie v. J.P. Morgan Chase Bank, No. 08 CV 07688LAP, 08 CV 07982, 2009 WL 234128, at *1 (S.D.N.Y. 2009).

100 Id.

101 In re Snell \& LeCroy, Exchange Act Release No. 330, 2007 WL 1297008 (May 3, 2007) [hereinafter Snell \& LeCroy Release] .

${ }^{102}$ Sch. Dist. of Erie, 2009 WL 234128, at*1 (citing Snell \& LeCroy Release, supra note 101 , at $* 32-33)$. 
rate in the swaption was the interest rate on the School Bonds. ${ }^{103}$ Moreover, according to the court, the only material term in the swap was the floating rate, which was based on LIBOR. ${ }^{104}$ Therefore, like the court in St. Matthew's, the court in School District of Erie found that, because LIBOR is an interest rate, a material term of the swaption was not based "on the price, yield, value, or volatility of any security, or any group, or index of securities" and thus was not a security-based swap agreement. ${ }^{105}$

The district court's reasoning in School District of Erie is almost incomprehensible. ${ }^{106}$ It is hard to understand how the holding in Snell $\mathcal{E}$ LeCroy is relevant to the School District of Erie decision. Perhaps the court was suggesting inartfully that the Snell $\mathcal{E}$ LeCroy holding informs the meaning of "based on" in the security-based swap agreement definition-that, just as entering into a swap at the same time as a related bond transaction does not create a sufficient nexus for the swap and the bonds to be considered a single transaction, neither does the fact that the fixed rate in the School District of Erie swaption was determined using the fixed rates on the School Bonds mean that the fixed rate in the swaption was "based on" the fixed rates on the School Bonds.

If the court indeed was suggesting that Snell $\mathcal{E}$ LeCroy applied analogously, this suggestion seems off the mark. Whether two separate transactions should be treated as a single transaction-which was the issue in Snell $\mathcal{E}$ LeCroy-is different from whether a term in a document is based on something else. Snell $\mathcal{E}$ LeCroy dealt with whether interest rate swaps related to certain bonds could be considered "municipal securities business" and therefore subject to Municipal Securities Rulemaking Board (MSRB) jurisdiction. ${ }^{107}$ Because the MSRB had jurisdiction over municipal bond transactions, but "no jurisdiction over derivatives in the municipal market," the transactions needed to be collapsed if MSRB jurisdiction were to apply to the swaps. $^{108}$ A Snell $\mathcal{E}$ LeCroy-styled argument in School District of Erie

103 Id.

104 Id.

${ }^{105}$ Id.; see also Gramm-Leach-Bliley Act $\$ 206 \mathrm{~B}, 15$ U.S.C. $\$ 78 \mathrm{c}$ note (2006), repealed by Dodd-Frank Act, Pub. L. No. 111-203, § 762(a), 124 Stat. 1376, 1759 (2010) (amending 15 U.S.C. $§ 78$ c note) (defining "security-based swap agreement")

${ }^{106}$ Understanding the court's reasoning is very difficult because the court did not issue an "opinion" in the case, but instead had a transcript of the proceedings prepared. See Sch. Dist. of Erie, 2009 WL 234128 (representing a transcript of proceedings).

Snell \& LeCroy Release, supra note 101, at*32.

${ }^{108}$ Id. 
would have been that the swaption and the School Bonds together were a single transaction, and because the School Bonds are securities $^{109}$ subject to Exchange Act section 10(b) and Rule 10b-5, the swaption also is subject to those provisions. This, however, was not the plaintiffs' argument. ${ }^{110}$ In School District of Erie, the plaintiffs asserted that the swaption was subject to section $10(\mathrm{~b})$ and Rule 10b-5, not because the swaption and the School Bonds together represented a single security, but because the swaption had a fixed rate based on the interest rates on the School Bonds and therefore was a securitybased swap agreement. ${ }^{111}$

The School District of Erie opinion and the related briefs with respect to the defendant's motion to dismiss do not indicate exactly how the fixed rate in the swaption related to the fixed interest rates on the School Bonds, but it is not uncommon for the fixed rate in a synthetic refunding swaption to equal the average interest rate on the outstanding bonds. ${ }^{112}$ If that was the case in School District of Erieand, based on the allegations in the complaint and the plaintiffs' brief in opposition to the defendant's motion to dismiss, it probably was-it seems hard to argue that the fixed rate in the swaption was not based on the interest rates on the bonds. Similar to the swap in St. Matthew's, the fixed interest rates on the School Bonds were more

109 There is no question that the bonds were securities. See 15 U.S.C. $\$ \S$ $77 b(a)(1), 77 c(a)(2)$ (2006) (including "bond" in the definition of "security" and specifying that a "security issued . . . by any political subdivision of a State . . ., or by any public instrumentality of one or more States" is an exempted security); $i d$. $\S$ 78 c(a) (10) (including "bond" in the definition of "security"); id. §78c(a) (12) (A) (ii), (a) (29) (defining "securities which are direct obligations of . . . a State or any political subdivision thereof, or any agency or instrumentality of a State or any political subdivision thereof" as exempted securities); Erie Complaint, supra note 90, If 2 (stating that the Butler County General Authority, the issuer of the bonds, "is a public instrumentality and body corporate and politic in the Commonwealth of Pennsylvania”).

${ }^{110}$ In fact, the argument would not have made sense in Erie because the bonds were issued two or more years before the swaption. See Erie Complaint, supra note 90, II 8,40 (indicating that the swaps were entered into in 2003 and the bonds were denominated as a 2000 series).

${ }^{111}$ See School District Brief, supra note 92, at 6 (noting that one of the material terms of the swaption was "the fixed rate of the School [Bonds]").

112 The HandBook OF Municipal Bonds, supra note 90, at 310. DEC Associates, Inc. ("DEC"), a swap advisor that assisted the County of Dare, North Carolina, in 2005, described a swaption with UBS structured in this way. DEC Assocs., INC., CNTY. OF DARE, N.C., PRELIMINARY SWAP ANALYSIS (2005), available at http://www.darenc.com/BOC/2005/Attachments/0516at6.pdf. According to DEC, in the UBS swaption structure, "[i]f UBS exercise[d] the option, . . . the County [would] pay UBS a fixed swap rate equal to the average coupon of the [debt to be refinanced]." Id. 
than a fundamental part of determining the fixed rate under the swaption. Therefore, applying Rorech's interpretation, a term of the swaption-its fixed rate-was based on the interest rate of a security.

Even more perplexing than School District of Erie's reference to Snell Eं LeCroy is the court's statement that the "only material term" under the swaption was the floating rate, which was based on LIBOR. $^{113}$ It is hard to imagine an interest rate swap-or any other contract for that matter-with a single material term. At a minimum, a floating-to-fixed interest rate swap has three material terms: the floating rate, the fixed rate, and the notional amount. Without all three, there is no swap.

The only real issue in School District of Erie-and the one the court ignored-was whether the fact that the fixed rate in the swaption was determined from the fixed rates on the School Bonds meant that either the floating rate or fixed rate in the swaption was based on the price, yield, value or volatility of an interest in the School Bonds. The School District of Erie swaption otherwise met the definition of "security-based swap agreement."

The plaintiffs in School District of Erie tried to help the court distinguish the School District of Erie swaption from the swap at issue in St. Matthew's by pointing out that the floating rate in the St. Matthew's swap was the same as the interest rate in a note, which was not a security, and that the fixed rate in the School District of Erie swaption was determined from the fixed rates on the School Bonds, which were se-

113 Sch. Dist. of Erie v. J.P. Morgan Chase Bank, No. 08 CV 07688LAP, 08 CV 07982, 2009 WL 234128, at*1 (S.D.N.Y. 2009).

114 The swaption was a swap agreement because it was an option on an interest rate swap, which specifically is included in the GLBA § 206A definition. See GrammLeach-Bliley Act $\S \S 206 \mathrm{~A}(\mathrm{a})(3), 206(\mathrm{a})(5), 15$ U.S.C. $§ 78$ c note (2006) (including an interest rate swap in paragraph (3) and providing that an option on an agreement, contract or transaction described in paragraph (3) is included in the definition of "swap agreement"). The court in School District of Erie did not address this point, but the defendant admitted as much. JP Morgan Motion to Dismiss, supra note 93 , at 7 . Because the fixed rate in the swaption most likely represented the average fixed interest rate on the School Bonds, the swaption's fixed rate easily could be considered based on the School Bonds, which were securities. See supra note 112 and accompanying text (describing how the swaption may have been structured); supra note 109 (indicating that municipal bonds are securities). The fixed rate under the swaption was material because, in Rorech terms, it "was plainly part of, if not all of, the consideration for which" J.P. Morgan agreed to make LIBOR-based floating rate payments. SEC v. Rorech, 720 F. Supp. 2d 367, 408 (S.D.N.Y. 2010). Moreover, it was the rate on which J.P. Morgan would base its decision as to whether to exercise the swaption. If market rates stayed below the fixed rate in the swaption, J.P. Morgan would exercise the swaption so that it would receive the higher fixed rate. If market rates rose above the fixed rate in the swaption, J.P. Morgan would not exercise it, benefiting instead from the higher market rates. 
curities. ${ }^{115}$ The School District of Erie court did not attach any significance to this distinction, however, and relied instead-with what appears to be little thought—on the fact that the St. Matthew's “[c] ourt's analysis went exclusively to the LIBOR rate and said nothing about the underlying." ${ }^{116}$ Because the St. Matthew's swap was floating-tofixed and the floating rate corresponded to the interest rate under the note, the court in that case appropriately focused on the LIBORbased floating rate. In contrast, the School District of Erie court should have focused on the fixed rate under the swaption because it related to the interest rates on the School Bonds. By failing to do so, the School District of Erie court missed the real issue.

\section{Caiola, Elliott, Wyly, and Goldman Sachs}

The United States District Court for the Southern District of New York was the first court to give the term "security-based swap agreement" any specific attention, but the attention it gave was not terribly meaningful. In Caiola v. Citibank, N.A., the court considered a private cause of action under Exchange Act section 10(b) and Rule $10 \mathrm{~b}-5$ with respect to, among other things, equity swaps entered into prior to the enactment of the CFMA. ${ }^{117}$ The Caiola equity swaps consisted of agreements under which Louis Caiola, the plaintiff, agreed to pay to Citibank "interest" on a notional amount representing the price of a specified number of shares of Philip Morris stock, plus the amount of any losses resulting from decreases in the price of the stock. ${ }^{118}$ In exchange, Citibank agreed to pay Caiola the amount of any dividends paid on the Philip Morris shares, plus the amount of any gains resulting from increases in the price of the stock. ${ }^{119}$

${ }^{115}$ School District Brief, supra note 92, at 6 .

116 Sch. Dist. of Erie, 2009 WL 234128, at*1.

117 Caiola v. Citibank, N.A., 137 F. Supp. 2d 362, 365 n.1, 366-67, 372 (S.D.N.Y. 2001).

${ }^{118}$ Caiola v. Citibank, N.A., 295 F.3d 312, 316 (2d Cir. 2002).

119 Id. The Second Circuit gave the following example of how the Caiola equity swaps worked:

[I]f Caiola synthetically purchased 1000 shares of Philip Morris at $\$ 50$ per share, the notional value of that transaction would be $\$ 50,000$. Because this notional value would resemble a loan from Citibank, Caiola would pay interest at a predetermined rate on the $\$ 50,000$. If Philip Morris's stock price fell $\$ 10$, Caiola would pay Citibank $\$ 10,000$. If the stock price rose $\$ 10$, Citibank would pay Caiola $\$ 10,000$. Citibank also would pay Caiola the value of any dividends that Caiola would have received had he actually owned 1000 physical shares. 
The District Court discussed the CFMA amendments to section 10 (b) and stated, without any analysis, that the equity swaps "indisputably" would have been subject to section $10(\mathrm{~b})$, as amended, had they been entered after the CFMA was enacted. ${ }^{120}$ In an appeal of the dismissal of the case, the United States Court of Appeals for the Second Circuit, also without analysis, similarly indicated that, "had Caiola entered into his [equity swaps] after the enactment of the CFMA, they clearly would [have been] covered under Rule 10b-5." ${ }^{121}$

Although the district court and the Second Circuit in Caiola merely stated conclusions without any analysis, their conclusions that the equity swaps at issue in the case were security-based swap agreements were undoubtedly correct. GLBA section 206A specifically includes equity swaps in the definition of swap agreement. ${ }^{122}$ The Caiola swaps provided that payments were to be exchanged as a result of changes in the price of Philip Morris stock. ${ }^{123}$ Therefore, a term of each swap related to a price $e^{124}$ and the price was of traditional stock-a security. ${ }^{125}$ The relationship between the term and the price of the stock was direct. If the price of Philip Morris stock went up or down, payments equal to the entire amount of the increase or decrease multiplied by the notional amount were due. Price did not merely represent a fundamental part of the term; the term had no meaning without price. If the phrase "based on" in the definition of "security-based swap agreement" does not include such a close relationship, it is hard

120 Caiola, 137 F. Supp. 2d at 371.

121 Caiola, 295 F.3d at 327.

122 Gramm-Leach-Bliley Act $\S 206 \mathrm{~A}(\mathrm{a})(3), 15$ U.S.C. $\$ 78$ c note (2006). Under GLBA section $206 \mathrm{~A}(\mathrm{a})$, the agreement must be "between eligible contract participants" and "the material terms of [the agreement] (other than price and quantity) [must be] subject to individual negotiation." Id. § 206A(a). Citibank was, and Caiola almost assuredly was also, an eligible contract participant. See 7 U.S.C. § la(12) (A) (i), (xi) (2006) (including in the definition of "eligible contract participant" financial institutions and individuals with total assets in excess of $\$ 10$ million); see also supra note 32 (discussing the definition of "eligible contract participant"). The Second Circuit described Caiola as a "sophisticated investor" and "a major client of Citibank Private Bank." Caiola, 295 F.3d at 315. Moreover, Caiola and Citibank assuredly negotiated the terms of the equity swaps. See id. at 317-18 (describing the master agreement and trade confirmations Caiola and Citibank executed).

123 See Caiola, 295 F.3d at 316.

124 The equity swaps also provided that Citibank would pay to Caiola the amount of any dividends paid on Philip Morris shares. Id. Because the swaps required payments determined in reference to changes in price, one need not determine whether the term requiring the payment of dividends is based on price, yield, value, or volatility for purposes of the definition of security-based swap agreement.

${ }^{125}$ See 15 U.S.C. $\$ 77 b(a)(1)$ (2006) (including "stock" in the definition of "security"); $i d$. $\S 78 \mathrm{c}$ (a) (10) (same); Landreth Timber Co. v. Landreth, 471 U.S. 681, 687 (1985) (concluding that traditional stock clearly is a security). 
[Vol. 42:953

to imagine that any relationship could satisfy the definition. Finally, the term represented a significant portion of the consideration under the agreement and therefore was material.

In Elliott Associates v. Porsche Automobil Holding SE, the United States District Court for the Southern District of New York considered whether swaps that referenced Volkswagen's stock, which is listed on a German stock exchange, were subject to Exchange Act section 10(b) and Rule 10b-5. ${ }^{126}$ The swaps in Elliott were similar to the equity swaps in Caiola -in that they required the plaintiffs to make payments to the swap counterparties when Volkswagen's stock price rose and required the counterparties to make payments to the plaintiffs when Volkswagen's stock price fell. ${ }^{127}$ The issue in the case, however, was not whether the swaps were security-based swap agreements-the court, without discussion, referred to them as such-but whether section 10(b) and Rule 10b-5 applied to a security-based swap agreement with respect to a security listed on a foreign exchange. ${ }^{128}$ Looking to the Supreme Court's decision in Morrison v. National Australia Bank $L t d .,{ }^{129}$ the district court determined that section $10(\mathrm{~b})$ and Rule 10b5 did not apply. ${ }^{130}$

SEC v. Wyly involved allegations of illegal insider trading under Exchange Act section 10(b) and Rule 10b-5 with respect to a swap in which five companies were to receive gains from, and pay losses on, two million shares of Sterling Software, Inc. stock. ${ }^{131}$ In its complaint, the SEC described the swap as a "security-based swap agreement." The swap, however, was entered into prior to enactment of the CFMA, a point that the defendants raised in moving for dismissal of the insider trading claims. ${ }^{133}$ Accordingly, in ruling on the defendants' motion, the court did not consider whether the swap fit the CFMA definition.

Finally, in SEC v. Goldman Sachs E Co., the SEC claimed violations of Securities Act section 17(a) and Exchange Act section 10(b)

126759 F. Supp. 2d 469, 470 (S.D.N.Y. 2010).

${ }^{127}$ Memorandum of Law in Support of Defendant Porsche Automobil Holding SE's Motion to Dismiss Pursuant to Rule 12(b) (6) or on the Basis of Forum Non Conveniens at 8, Elliott Assocs. v. Porsche Auto. Holding SE, 759 F. Supp. 2d 469 (S.D.N.Y. 2010) (Nos. 10 Civ. 0532 (HB), 10 Civ. 4155 (HB)).

${ }^{128}$ Elliott Assocs., 759 F. Supp. 2d at 475.

129130 S. Ct. 2869 (2010).

${ }^{130}$ Elliott Assocs., 759 F. Supp. 2d at 476.

131788 F. Supp. 2d 92, 97 n.37 (S.D.N.Y. 2011).

132 Complaint If 77, SEC v. Wyly, 788 F. Supp. 2d 92 (S.D.N.Y. 2011) (No. 10 Civ. 5760), 2010 WL 3133915.

${ }^{133}$ Wyly, 788 F. Supp. 2d 92 at 120. 
and Rule 10b-5 with respect to CDSs related to a synthetic collateralized debt obligation known as ABACUS 2007-AC-1. ${ }^{134}$ The SEC's complaint alleged that the swaps were security-based swap agreements, and while the defendant did not "concede that the SEC's characterization ... [was] correct," ${ }^{, 135}$ he did not argue the point in his motion to dismiss. ${ }^{136}$ Therefore, the court's opinion regarding the defendant's motion does not address whether the swaps were in fact security-based swap agreements.

The Elliott, Wyly, and Goldman Sachs opinions are short on details as to the actual mechanics of the swaps at issue in those cases. Nevertheless, it seems very likely that the swaps in those cases would meet the definition of security-based swap agreement. With payments being exchanged based on gains and losses with respect to Volkswagen and Sterling Software stock, the swaps in Elliott and Wyly were similar to those at issue in Caiola and likely would be security-based swap agreements for the same reasons as the Caiola swaps were. Similarly, the Goldman Sachs CDSs almost certainly were priced taking into account securities associated with ABACUS and therefore were likely security-based swap agreements for the reasons cited in Rorech.

\section{LANGFORD AND LECROY}

Rorech was the first substantive opinion regarding SEC enforcement of a security-based swap agreement, but the SEC's first enforcement action with respect to an alleged security-based swap agreement was filed two years earlier, in April 2008, against Larry Langford, the then-mayor of Birmingham, Alabama and former president of the Jefferson County, Alabama, commission; Blount Parrish \& Co., Inc., a Montgomery, Alabama, broker-dealer; William Blount,

134 SEC v. Goldman Sachs \& Co., 790 F. Supp. 2d 147, 147 (S.D.N.Y. 2011). [CDOs] are debt securities collateralized by debt obligations, including [RMBSs]. These securities are packaged and generally held by a special purpose vehicle that issues notes entitling their holders to payments derived from the underlying assets. In a synthetic CDO, the special purpose vehicle does not own a portfolio of [RMBSs], but enters into credit default swaps . . . that reference the performance of the portfolio.

$I d$. at 150 n.2. For further discussion of how CDOs work, see In re Sec. Capital Assurance, Ltd. Sec. Litig., 729 F. Supp. 2d 569, 574-76 (S.D.N.Y. 2010).

${ }_{135}$ Reply Memorandum of Law of Fabrice Tourre in Support of His Motion to Dismiss the Amended Complaint at 8 n.11, SEC v. Goldman Sachs \& Co., 790 F. Supp. 2d 147 (S.D.N.Y. 2011) (No. 10-cv-3229), 2011 WL 1291012.

See generally Memorandum of Law of Fabrice Tourre in Further Support of His Motion to Dismiss the Amended Complaint at 8 n.11, SEC v. Goldman Sachs \& Co., 790 F. Supp. 2d 147 (S.D.N.Y. 2011) (No. 10-cv-3229), 2010 WL 5889174. 
a co-owner of Blount Parrish; and Albert LaPierre, an Alabama lobbyist. $^{137}$ In SEC v. Langford, the SEC alleged that Langford, Blount, Blount Parrish, and LaPierre violated Securities Act section 17(a) and Exchange Act section 10(b) and Rule 10b-5 in connection with four interest rate swaps (valued at approximately $\$ 3.5$ billion in total) entered into by Jefferson County with respect to various series of bonds issued by the county. ${ }^{138}$ In 2009 , the SEC initiated a related enforcement action against Charles LeCroy and Douglas MacFaddin, both of whom were managing directors of J.P. Morgan Securities, Inc. ${ }^{139}$ In SEC v. LeCroy, the SEC claimed violations of Securities Act section 17 (a) and Exchange Act section 10(b) and Rule 10b-5 with respect to the three interest rate swaps (valued at approximately $\$ 2$ billion in total) at issue in Langford that had been entered into between the county and JPMorgan Chase Bank, N.A., a commercial bank affiliated with J.P. Morgan Securities. ${ }^{140}$

All of the interest rate swaps at issue in Langford and LeCroy provided that one of the parties would make floating rate payments determined in reference to the Securities Industry and Financial Markets Association's (SIFMA) Municipal Swap Index ("the SIFMA Index"). ${ }^{141}$ The SEC alleged in the Langford and LeCroy complaints

${ }^{137}$ See Langford Complaint, supra note 20; see also Langford Release, supra note 19 ("The case is the SEC's first enforcement action involving security-based swap agreements.").

138 Langford Complaint, supra note 20, II 1-5, 11-12. The various series of "bonds" that the SEC refers to in its complaint technically are denominated "warrants." See, e.g., JefFerson Cnty, Official Statement REgarding \$1, 155,765,000 Jefferson County, Alabama, Sewer Revenue Refunding Warrants, Series 2003-B (2003), available

http://jeffco.jccal.org/pls/portal/docs/PAGE/FINANCE_PAGE_GROUP/

INVESTOR_RELATIONS/TAB60915/2003-B\%20OFFICIAL\%20STATEMENT.PDF. In the SEC's related enforcement action against Charles LeCroy and Douglas MacFaddin, MacFaddin's motion to dismiss appropriately referred to the Jefferson County "bonds" as "warrants." Defendant Douglas W. MacFaddin's Motion to Dismiss at 5, SEC v. LeCroy, No. 2:09-cv-02238 (N.D. Ala. Jan. 15, 2010) [hereinafter MacFaddin Motion to Dismiss]. The SEC presumably referred to the "warrants" as "bonds" because the warrants would have had to have met the definition of "State or local bond" under the Internal Revenue Code in order to be tax exempt. See 26 U.S.C. $\$ 103$ (2006) (excluding interest on state and local bonds from gross income). Consistent with the SEC's nomenclature, this Article also refers to the "warrants" as "bonds."

139 SEC Charges Two Former Directors of J.P. Morgan Securities with Fraud in Connection with Unlawful Payment Scheme to Obtain Municipal Bond and Swap Business, Litigation Release No. 21280, 2009 WL 3631040 (Nov. 4, 2009).

${ }^{140}$ LeCroy Complaint, supra note 21, III 2, 5.

${ }^{141}$ Langford Complaint, supra note 20, If 16; LeCroy Complaint, supra note 21, II 18-19. When the swaps were entered into, the index was called The Bond Market Association Municipal Swap Index (the "BMA Index"). See id. II 16 (referring to the 
that the swaps were security-based swap agreements because the floating rate payments were based "on the value" of the SIFMA Index and the SIFMA Index is an index of securities that was "used to establish the floating rate yield." "The defendants disagreed with the SEC's characterization of the swaps and filed motions to dismiss the SEC's claims.

No decision will be forthcoming in Langford as to whether the SIFMA Index swaps were security-based swap agreements. The SEC's enforcement actions against Blount, Blount Parrish \& Co., Inc., and LaPierre were resolved by consent judgments in July $2010 .{ }^{143}$ In March 2011, without issuing an opinion, the United States District Court for the Northern District of Alabama denied Langford's motion to dismiss, ${ }^{144}$ and in August 2011, the court granted summary judgment against Langford in the SEC's enforcement action without a determination as to whether the Jefferson County swaps were security-based swap agreements. ${ }^{145}$

BMA Index); LeCroy Complaint, supra note 21, II 18-19 (same); Answering Your Questions About the Securities Industry and Financial Markets Association (SIFMA) Municipal Swap Index, SIFMA (Nov. 1, 2010), http://www.sifma.org/research/item.aspx?id=1690 [hereinafter About SIFMA] (indicating that the SIFMA Index formerly was referred to as the BMA Index). SIFMA is the successor to the Bond Market Association. Id.

${ }^{142}$ Langford Complaint, supra note 20, II 16; LeCroy Complaint, supra note 21, II $18-19$.

${ }^{143}$ SEC v. Langford, No. 2:08-cv-00761-AKK (N.D. Ala. July 14, 2010) (order granting final judgment and permanent injunction as to Albert W. LaPierre); SEC v. Langford, No. 2:08-cv-00761-AKK (N.D. Ala. July 14, 2010) (order granting final judgment and permanent injunction as to William B. Blount); SEC v. Langford, No. 2:08-cv00761-AKK (N.D. Ala. July 14, 2010) (order granting final judgment and permanent injunction as to Blount Parish \& Co., Inc.).

${ }^{144}$ SEC v. Langford, No. 2:08-cv-00761-AKK (N.D. Ala. March 30, 2011) (order denying motion to dismiss).

${ }^{145}$ SEC v. Langford, No. 2:08-cv-761-AKK (N.D. Ala. Aug. 8, 2011). In March 2010, Langford was convicted on sixty-one counts of bribery, conspiracy, money laundering, mail fraud, wire fraud, filing false personal income tax returns, and criminal forfeiture. See United States v. Langford, 647 F.3d 1309, 1314, 1319 (11th Cir. 2011); Sherrel Stewart, Former Birmingham Mayor Larry Langford Reports to Federal Prison in Kentucky, BIRMINGHAM NEws (Apr. 7, 2010, 11:30 AM), http://blog.al.com/spotnews/2010/04/former_birmingham_mayor_larry_4.html. The SEC's claims in Langford included not only fraud claims with respect to the swaps, but also fraud claims with respect to the related bonds. Langford Complaint, supra note 20, III 11, 14. In its summary judgment motion, the SEC argued that Langford's conviction estopped him from disputing the allegations in the SEC's enforcement action and that the resolution of whether the swaps were security-based swap agreements was unnecessary because there was no dispute that the activities complained of were in connection with bonds, "which are undeniably securities," subject to Securities Act section 17(a) and Exchange Act section 10(b) and Rule 10b5. Plaintiff's Motion for Summary Judgment Against Defendant Larry P. Langford at 
In LeCroy, the District Court denied LeCroy's and MacFaddin's motions to dismiss on procedural grounds without reaching a conclusion as to whether the relevant Jefferson County swaps were securitybased swap agreements. ${ }^{146}$ An answer to the question remains possible in that case.

\section{A. Arguments of the Defendants and SIFMA}

In support of their motions to dismiss, the defendants in Langford and LeCroy argued that the Jefferson County swaps were not security-based swap agreements for two reasons. First, the SIFMA Index is not an index of securities, but an index of interest rates. ${ }^{147}$ Second, even if the SIFMA Index were an index of securities, no material term of any of the swaps was based on "the price, yield, value or volatility" of the SIFMA Index. ${ }^{148}$

SIFMA made the same arguments in an amicus curiae brief that it filed in Langford. ${ }^{149}$ In the brief, SIFMA explained how the SIFMA Index works. According to SIFMA, the SIFMA Index is calculated based on interest rates from over 600 tax-exempt variable rate demand obligations (VRDOs) whose rates are adjusted each week to reflect existing market conditions. ${ }^{150}$ SIFMA noted that the database

1-2, 9, 14 n.3, SEC v. Langford, No. 2:08-cv-00761-AKK (N.D. Ala. July 16, 2010); Plaintiff's Renewed Motion for Summary Judgment Against Defendant Larry P. Langford, SEC v. Langford, No. 2:08-cv-00761-AKK (N.D. Ala. Aug. 8, 2011).

${ }^{146}$ See SEC v. LeCroy, No. 2:09-cv-02238, slip op. at 2 (N.D. Ala. Aug. 4, 2010) (denying the defendants' motions and noting that the question of whether the Jefferson County swaps were security-based swap agreements was one that "[the] court [could not] resolve ... on a motion to dismiss").

${ }^{147}$ See Motion to Dismiss of William B. Blount and Blount Parrish \& Co., Inc. at 11-14, SEC v. Langford, No. 2:08-cv-00761-AKK (N.D. Ala. June 27, 2008) [hereinafter Blount Motion to Dismiss]; Motion of Charles LeCroy to Dismiss Complaint at 811, Securities Exchange Commission v. LeCroy, No. 2:09-cv-02238 (N.D. Ala. Jan. 19, 2010) [hereinafter LeCroy Motion to Dismiss]; MacFaddin Motion to Dismiss, supra note 138, at 13-18. Langford and LaPierre filed motions to dismiss that incorporated the motion to dismiss of Blount and Blount Parrish. Motion to Dismiss of Albert W. LaPierre, SEC v. Langford, No. 2:08-cv-00761-AKK (N.D. Ala. June 30, 2008); Motion to Dismiss of Larry P. Langford, Securities and Exchange Commission v. Langford, No. 2:08-cv-00761-AKK (N.D. Ala. June 30, 2008).

${ }_{148}$ See Blount Motion to Dismiss, supra note 147, at 14-15; LeCroy Motion to Dismiss, supra note 147, at 7-8; MacFaddin Motion to Dismiss, supra note 138, at 18-22.

${ }^{149}$ See Brief for Securities Industry and Financial Markets Association as Amicus Curiae Supporting Defendants at 14-25, SEC v. Langford, No. 2:08-cv-00761-AKK (N.D. Ala. Aug. 7, 2008) [hereinafter SIFMA Brief].

${ }^{150} I d$. at 9. "[VRDOs] are financial instruments whose yield is reset [by a remarketing agent] on a regular basis, such as daily, weekly, monthly or even semiannually[,] . . . to bring it in line with the broader interest rate market." THE HANDBOOK OF MUNICIPAL BONDS, supra note 90, at 1129-30. VRDOs typically allow an investor to tender its security on each reset date at a price equal to par plus accrued 
used to calculate the index is controlled by Municipal Market Data (MMD), that the identities of the specific VRDOs used to calculate the index are not known to SIFMA, and that the VRDOs used in the index change from week to week. ${ }^{151}$ SIFMA also indicated that only interest rates are used to calculate the index and that " $[0]$ ther terms of the [VRDOs]... are not reported as part of the [index]."152 SIFMA asserted that, accordingly, the SIFMA Index is intended to be a "benchmark interest rate." 153

To support its claim that the SIFMA Index is an index of interest rates, not securities, SIFMA cited the fact that SIFMA Index swaps are used to hedge against interest rate fluctuations. ${ }^{154}$ Moreover, according to SIFMA, the SIFMA Index "is well understood in the marketplace... [as] the tax-exempt market equivalent of LIBOR, which is an index of ... interest rates." ${ }^{155}$ Referring to the conclusion in St. Matthew's that LIBOR-based swaps are not security-based swap agreements, SIFMA argued that it would be inconsistent to determine that a SIFMA Index swap is a security-based swap agreement when its most common alternative-a LIBOR swap-is not a security-based swap agreement. ${ }^{156}$ SIFMA acknowledged that the VRDOs used to calculate the SIFMA Index are securities, but asserted that the use of VRDOs for the calculation does not mean that the index is an index of securities. $^{157}$ According to SIFMA, the only reason that the interest rates

interest, and the remarketing agent sets each rate so that tendered obligations may be resold at par. Id. at 1130; Robert A Fippinger, The SeCurities LAw OF Public FINANCE $§ 5: 3.4[\mathrm{~B}]$ (2d ed. 2010).

151 SIFMA Brief, supra note 149, at 10.

${ }^{152} I d$.

${ }^{153}$ Id. at 22. MacFaddin argued that the fact that no other terms of the VRDOs are involved in calculating the SIFMA Index indicates that the SIFMA Index solely is a "benchmark interest rate." MacFaddin Motion to Dismiss, supra note 138, at 14.

154 SIFMA Brief, supra note 149, at 20.

${ }^{155} I d$. at 8. In his reply brief to the SEC's response to his motion to dismiss, MacFaddin clarified that "LIBOR is not 'based on' a bank lending rate, [but] is a bank lending rate . . . 'based on' the interest rates on loans made between banks." Defendant Douglas W. MacFaddin's Reply in Further Support of His Motion to Dismiss at 12 n.10, SEC v. LeCroy, No. 2:09-cv-02238 (N.D. Ala. Feb. 17, 2010) [hereinafter MacFaddin Reply].

${ }^{156}$ SIFMA Brief, supra note 149 , at 22. MacFaddin made a similar claim. See MacFaddin Motion to Dismiss, supra note 138, at 16-18 (arguing that the SIFMA Index is an alternative to LIBOR and that treating the two differently would be inappropriate).

${ }^{157}$ SIFMA Brief, supra note 149, at 19; see also Reply Brief of the Securities Industry and Financial Markets Association in Support of its Motion for Leave to File a Brief Amicus Curiae at 8, SEC v. Langford, No. 2:08-cv-00761-AKK (N.D. Ala. Jan. 19, 2010) [hereinafter SIFMA Reply]. 
used in the SIFMA Index are those from securities is that tax-exempt interest rates apply only to municipal bonds, ${ }^{158}$ which are securities.

In arguing that no material term of any of the swaps was based on the value or yield of the SIFMA Index, SIFMA asserted that the swaps could not be based on the value of the index because the index does not include values but interest rates. ${ }^{159}$ MacFaddin added that characterizing the SIFMA Index as the value of the underlying securities is inconsistent with the distinction between "value" and "level" in the definition of "swap agreement." 160 The term "level," MacFaddin argued, applies to interest rates, while the term "value" applies to true indexes of securities, which measure the performance of the securities in the index. ${ }^{161}$ SIFMA, Blount, and MacFaddin all contended that the SIFMA Index does not represent a yield because, to calculate yield on a debt instrument, one must have not only the interest rate, but also the purchase price, the rate at which interest accrues, and the holding period. ${ }^{162}$ MacFaddin noted that an "[i]nterest rate is an express term of a bond (like principal amount and maturity date), while yield is not. Yield is a mathematical calculation using components that reflect market conditions and other factors (including the interest rate)."

In addition to their specific arguments, SIFMA, Blount, and MacFaddin argued broadly that Congress did not intend the term security-based swap agreement to include interest rate swaps. SIFMA contended that, because of pre-CFMA case law that held that the securities laws did not apply to interest rate swaps, for the term "security-based swap agreement" to include interest rate swaps, Congress needed to state so explicitly. ${ }^{164}$ Blount observed that, under the definition adopted by the International Swaps and Derivatives Association (ISDA) and incorporated by reference in the Jefferson County swap documents, the SIFMA Index means "the index which is issued weekly and is compiled from the weekly interest rate resets of tax-exempt vari-

${ }^{158}$ SIFMA Reply, supra note 157 , at 8 . MacFaddin made a similar argument. See MacFaddin Reply, supra note 155, at 12 ("The interest rates used in the SIFMA Index are derived from securities for the sole purpose of capturing a tax exempt rate. Interest is only tax exempt if it accrues on a municipal bond." (citations omitted)).

159 SIFMA Brief, supra note 149, at 23.

160 MacFaddin Motion to Dismiss, supra note 139, at 19.

${ }^{161} I d$. at 20.

162 SIFMA Brief, supra note 149, at 24; see Blount Motion to Dismiss, supra note 147, at 15 (citing the definition of yield used by the Municipal Securities Rulemaking Board); MacFaddin Motion to Dismiss, supra note 138, at 20-21.

${ }_{163}$ MacFaddin Motion to Dismiss, supra note 138, at 21.

164 SIFMA Brief, supra note 149, at 21. 
able rate issues included in a database maintained by Municipal Market Data." ${ }^{65}$ According to Blount, then, for the Jefferson County swaps to be security-based swap agreements, the definition of "security-based swap agreement" would need to be expanded to include not only "an index of securities," but also "an index of the rates of underlying securities." MacFaddin likewise claimed that, for SIFMA Index swaps to be subject to Securities Act section 17(a) and Exchange Act section $10(\mathrm{~b})$, one would need to interpret "index of securities" to mean "index of interest rates extracted from a group of securities." ${ }^{167}$ Moreover, MacFaddin maintained that the definition of "swap agreement" in GLBA section 206A separately states that there may be agreements based on "interest or other rates" and agreements based on "securities" or "instruments of indebtedness," and, in light of that, the only reasonable interpretation is that the term "security-based swap agreement" applies only to the latter. ${ }^{168}$

\section{B. Counterarguments of the SEC}

In responding to the defendants' motions to dismiss and SIFMA's amicus brief, the SEC argued primarily that, procedurally, the defendants had not met the legal standard required for dismissal. ${ }^{169}$ The SEC did, however, raise some substantive arguments. In Langford, the SEC argued that both the ISDA definition and the description of the SIFMA Index on SIFMA's website indicate that the SIFMA Index is an index of securities. ${ }^{170}$ The SEC focused on the fact that the rate identified in the ISDA definition references "an underlying index of "tax exempt variable rate issues" "171 and that the SIFMA web-

${ }^{165}$ Blount Motion to Dismiss, supra note 147, at 12 (quoting ISDA, SuPPLEMENT Number 19 TO THE 2000 ISDA DEFINITIONS AND ANNEX TO THE 2000 ISDA DEFINITIONS (2004) (emphasis added) (internal quotation marks omitted), available at http:/ /www.isda.org/publications/pdf/supplement-19-to-2000DefinitionsAnnex.pdf.

${ }^{166} I d$. at 13 (emphasis added).

167 MacFaddin Motion to Dismiss, supra note 138, at 15; see also MacFaddin Reply, supra note 155, at 12 (making a similar argument).

168 MacFaddin Motion to Dismiss, supra note 138, at 12.

${ }^{169}$ See Plaintiff's Response to Defendants' Motion to Dismiss at 38-46, SEC v. Langford, No. 2:08-cv-00761-AKK (N.D. Ala. July 14, 2008) [hereinafter SEC Response to Blount] (describing the SEC's procedural arguments against dismissal); Plaintiff's Consolidated Response to Motions to Dismiss of Defendants Charles LeCroy and Douglas MacFaddin at 10-21, SEC v. LeCroy, No. 2:09-cv-02238 (N.D. Ala. Feb. 9, 2010) [hereinafter SEC Response to LeCroy] (same); Plaintiff's Response to the Brief of the Securities Industry and Financial Markets Association at 12-18, SEC v. Langford, No. 2:08-cv-00761-AKK (N.D. Ala. August 27, 2008) [hereinafter SEC Response to SIFMA] (same).

${ }^{170}$ SEC Response to Blount, supra note 169 , at 47-49.

${ }^{171}$ Id. at 47. 
site describes the SIFMA Index as one consisting of VRDOs, which, the SEC noted, are bonds and "obviously securities."

In LeCroy, the SEC refined and expanded its argument. Similar to its approach in Langford, the SEC argued that "there is no doubt the interest rates used to calculate the [SIFMA] Index are interest rates on a group or index of bonds, which are securities." went further, however, and claimed that the interest rates on the VRDOs relevant to the SIFMA Index are the same as their yields because one of the key features of a VRDO is the ability of the holders to tender the obligations at par. ${ }^{174}$ The SEC noted that, as a result, many "experts" use the terms "interest rate" and "yield" interchangeably when discussing VRDOs. ${ }^{175}$ The SEC also argued that the interest rates on the VRDOs are closely related to the value and volatility of the underlying obligations because the rates on the obligations are determined based on comparable securities, credit ratings, and supply and demand, and because SIFMA controls the variation of interest rates in the index by eliminating obligations with interest rates that are outliers. ${ }^{176}$ According to the SEC, this was evidence that the SIFMA Index is based on an "interest" in the value or volatility of a "group of securities."

C. The Statutory Text Supports the Conclusion that a SIFMA Index

Swap Is a Security-Based Swap Agreement, but Policy Does Not

The SEC's arguments in Langford and LeCroy as to why the Jefferson County swaps were security-based swap agreements are not particularly well developed. Nevertheless, under a fair reading of the statute and in light of the flexibility apparently intended by Congress, the SEC's claim is not unfounded.

Of course, trying to divine what Congress intended to capture in the definition of the term "security-based swap agreement" is difficult in light of the scant legislative history with respect to the term. What

${ }^{172} I d$. at 48 n.13; see SEC Response to SIFMA, supra note 169, at 20 ("[T] he interest rates [in the SIFMA Index] are on bonds, which are undisputedly securities.").

173 SEC Response to SIFMA, supra note 169, at 22; SEC Response to LeCroy, supra note 169 , at 22 .

${ }^{174}$ SEC Response to SIFMA, supra note 169, at 22-23; SEC Response to LeCroy, supra note 169, at 23-24.

175 SEC Response to SIFMA, supra note 169, at 24; SEC Response to LeCroy, supra note 169 , at 24 .

176 SEC Response to SIFMA, supra note 169, at 25-26; SEC Response to LeCroy, supra note 169, at 25-26.

177 SEC Response to SIFMA, supra note 169, at 26; SEC Response to LeCroy, supra note 169 , at 26 . 
little can be gleaned from the legislative history, however, is that Congress wanted the term to sweep broadly to cover wrongdoing, particularly with respect to innovations in the swap market. ${ }^{178}$ In light of that intent, a narrow interpretation of the term seems unsuitable.

When analyzed based on its component parts, and taking into account Rorech's common-sense interpretation of the meaning of "based on," the definition of security-based swap agreement can reasonably be construed to include a SIFMA Index swap. ${ }^{179}$ First, a SIFMA Index swap is an interest rate swap, and an interest rate swap clearly is a swap agreement within the meaning of GLBA section 206A. As discussed above with respect to St. Matthew's and School District of Erie, interest rate swaps are specifically included in GLBA section 206A(a) (3). ${ }^{180}$ Second, the SIFMA Index can reasonably be said to be based on price. The floating rate in a SIFMA Index swap is not based on the SIFMA Index; it is the SIFMA Index. Therefore, in determining whether a SIFMA Index swap is a security-based swap agreement, one needs to determine whether the SIFMA Index itself is based on a price, yield, value, or volatility. SIFMA indicates that the interest rates used in the SIFMA Index are from VRDOs whose rates are adjusted

178 See, e.g., 146 Cong. REc. 27,309 (2000) (statement of Sen. Sarbanes) ("Title III [of the CFMA] applies anti-fraud and anti-manipulation provisions of the Federal Securities law to securities-based swap agreements .... This will enhance protection for investors and for the financial markets, and will permit the SEC to respond as necessary to developments in these markets.”); 146 Cong. REC. 27,078 (2000) (statement of Rep. Dingell) ("One of the most important provisions of the [CFMA] . . gives the SEC antifraud authority over securities-based swap agreements . . . This permits the SEC to use its tested methods to enhance the protection in [the swap] markets and to respond as necessary to developments in the future.").

179 See supra Part II.B (describing the component parts of the definition of "security-based swap agreement").

${ }^{180}$ Gramm-Leach-Bliley Act $§ 206 \mathrm{~A}(\mathrm{a})(3), 15$ U.S.C. $§ 78$ c note (2006); see supra notes 85, 114 and accompanying text (noting that the St. Matthew's and School District of Erie interest rate swaps were swap agreements under GLBA section 206A). Of course, prior to Dodd-Frank, for an interest rate swap to be a swap agreement under GLBA section 206A, it must have been between eligible contract participants, and the material terms (other than price and quantity) must have been subject to individual negotiation. See supra note 31 and accompanying text (quoting a portion of the definition of "swap agreement"). In the case of the Jefferson County swaps, these requirements were met. J.P. Morgan Chase Bank, N.A., Bear Stearns \& Co., and Jefferson County, Alabama, were all "eligible contract participants" under section 1a(12) of the CEA. See 7 U.S.C. § 1a(12)(A)(i), (A)(v), (A) (vi) (2006) (including financial institutions, corporations with assets exceeding $\$ 10$ million, and political subdivisions and instrumentalities of governmental entities owning or investing on a discretionary basis investments of $\$ 25$ million or more). In addition, as "negotiated swaps," the material terms of the Jefferson County swaps certainly were subject to individual negotiation. Bear Stearns \& Co. was the counterparty to the one Jefferson County swap that was at issue in Langford, but not in LeCroy. See Langford Complaint, supra note 20 , I 12. 
weekly. $^{181}$ The rate on each of those VRDOs is adjusted to the rate that is required to allow the obligation to be sold at a price of par. ${ }^{182}$ If Rorech is correct-that, for a matter to be "based on" a particular factor, that factor must represent a fundamental part of the matter-the interest rates on the VRDOs are based on their prices. There are other factors involved in determining the rates, but the par price is fundamental. Without it, one could not determine the rate. Third, the SIFMA Index is determined from a group of securities. Neither SIFMA nor the defendants disputed that the SIFMA Index is calculated from interest rates on over 600 VRDOs or that those VRDOs are securities. Finally, the floating rate in a SIFMA Index swap is a material term. It, along with the notional amount, determines the consideration for the fixed rate payments. Without the floating rate term, a floating-tofixed interest rate swap would not be enforceable or make any sense. $^{183}$

Moreover, in light of the flexible interpretation apparently intended by Congress, a court might go out of its way-for policy reasons-to find that an interest rate represents a yield, value, or volatility of an interest in a group of securities as the SEC seems to suggest. Consider an issuer that issues bonds that bear interest at (i) LIBOR plus one percent when the issuer's debt-to-equity ratio is less than or equal to two-to-one and (ii) LIBOR plus three percent when the ratio is greater than two-to-one. Several years after the bond issuance, the issuer becomes uncomfortable with the interest rate risk associated with its variable rate bonds and enters into a "cost-of-funds" interest rate swap ${ }^{184}$ under which the counterparty agrees to pay a floating rate equal to the actual interest rate on the bonds and the issuer pays a fixed rate equal to eight percent. The counterparty settled on the fixed rate because the issuer's debt-to-equity ratio had been no more than one-to-one since the bonds were issued and because the issuer's projections showed ratios of no more than one-to-one during the term of the swap. It turns out, however, that the issuer's projections

181 See About SIFMA, supra note 141 ("[F] or an issue to qualify for inclusion in the [SIFMA Index], it must . . . be a weekly reset ....").

182 See The HandBook OF Municipal Bonds, supra note 90, at 297 ("[F] or traditional [VRDOs], the rate . . . is set by the remarketing agent at a level that allows the bond [s] to be remarketed at a price of par.").

${ }_{183}$ See supra Part II.B.2 (citing Rorech's conclusion as to what constitutes a material term and discussing the material terms of a floating-to-fixed interest rate swap).

${ }^{184}$ A cost-of-funds swap is one in which the floating rate paid by the counterparty equals the actual interest rate on particular debt. See HANDBOok OF MUNICIPAL Bonds, supra note 90, at 306 (describing a cost-of-funds swap as one in which "floating leg receipts ... match the interest payments due on the hedged bonds exactly"). 
are fraudulent and the actual ratios exceed three-to-one six months into the swap. As a result, the interest rate on the bonds increases to LIBOR plus three percent, and the floating rate likewise increases to the detriment of the counterparty. If the cost-of-funds swap is not a security-based swap agreement, the counterparty would have no recourse against the issuer under Exchange Act section 10(b) and Rule $10 \mathrm{~b}-5$ with respect to the fraudulent projections on which the counterparty based the fixed rate. ${ }^{185}$ From a policy perspective, one would expect that such a cost-of-funds swap-one in which the floating rate is so intimately linked to a security-would be a security-based swap agreement subject to section $10(\mathrm{~b})$ and Rule 10b-5 because it presents securities-like fraud risk. For that reason, even if a conclusion that such an interest rate swap is a security-based swap agreement would require a tortured interpretation of the meaning of price, yield, value, or volatility, a court might be willing to entertain it. ${ }^{186}$

Although, based on the statutory text, a reasonable argument can be made that a SIFMA Index swap is a security-based swap agreement, such a result makes little sense from a policy perspective. ${ }^{187}$ Unlike the cost-of-funds swap described above, a SIFMA Index swap poses virtually no risk of nefarious activities related to the underlying securities. Because only MMD knows the identity of the component securities, such a large number of securities are involved, and the component securities change from week to week, it is hard to think of a situation in which a SIFMA Index swap would pose the fraud risks normally associated with securities. In a cost-of-funds swap, a party's knowledge of information with respect to the issuer of the applicable debt security can raise the possibility of securities-like fraud. In contrast, a party to a SIFMA Index swap will have no information about the identity of the VRDOs that are used to determine the interest rate. Even if a party did have such information, because

185 Because the issuer decided to enter into the swap several years after the bonds were issued, the counterparty could not argue that the fraud was in connection with the sale of the bonds and for that reason subject to section $10(\mathrm{~b})$ and Rule 10b-5. See SEC v. Zandford, 535 U.S. 813, 820, 822 (2002) (concluding that a fraud that coincides with securities transaction is subject to section $10(\mathrm{~b})$ and Rule 10b-5).

${ }^{186}$ Of course, SIFMA and the defendants in Langford and LeCroy could counter that, if such a tortured interpretation is necessary for such a cost of-funds swap to be included in the definition of "security-based swap agreement," Congress clearly could not have intended to include a SIFMA Index swap within the definition.

187 See AdAM W. GLaSS, "SCARY": SEC GETS IT WrOng IN Muni Swap ComplainT (2008), available at http://www.linklaters.com/pdfs/US/ScarySECgetsitwrong.pdf (indicating that the Jefferson County SIFMA Index swaps are "within the literal terms of the statute," but that treating them as security-based swap agreements does not make sense from a policy perspective). 
such a large number of obligations are involved, the component obligations change, and SIFMA makes adjustments for outliers, ${ }^{188}$ there is virtually no chance of profiting by misleading the other party to the swap regarding the underlying securities or their issuers.

Furthermore, as SIFMA and the defendants in Langford and LeCroy have pointed out, it seems inappropriate that a SIFMA Index swap would be a security-based swap agreement when its most common alternative-a LIBOR swap-is not. Like LIBOR, the SIFMA Index merely serves as a benchmark interest rate. Parties do not enter into SIFMA Index swaps as a substitute for investing in the over 600 VRDOs from which the index is determined. ${ }^{189}$

\section{DodD-Frank WALl StreEt REForm AND Consumer Protection ACT OF 2010}

Dodd-Frank introduced to the world of over-the-counter derivatives a new and extensive regulatory scheme that includes, among other things, information reporting, clearing, and exchange-trading requirements. $^{190}$ The reform law divides that world into two hemispheres-"swaps" and "security-based swaps." In general, swaps are subject to the jurisdiction of the CFTC and security-based swaps are subject to the jurisdiction of the SEC. ${ }^{191}$ Dodd-Frank included "security-based swaps" in the definition of "security" under both the Securities Act and the Exchange Act, thereby making them subject to the

188 See SIFMA Brief, supra note 149 , at 9-10 ("[I]n calculating the SIFMA . . Index, MMD (a) eliminates variable rate demand [obligations] whose interest rates fall outside of $+/-1.0$ standard deviations and (b) limits notes handled by a single remarketing agent to no more than $15 \%$ of the SIFMA . . Index.").

${ }^{189}$ See GLASS, supra note 187, at 2 ("In a municipal bond fixed-to-floating interest rate swap, ... the [SIFMA] Index is supposed to be a proxy for current tax-exempt market rates, not an investment medium ....").

190 See Dodd-Frank Act, Pub. L. No. 111-203, § 723, 124 Stat. 1376, 1675-82 (2010) (to be codified in 7 U.S.C. $\S 2$ ) (clearing of swaps); $i d . \S 727124$ Stat. at 1696-97 (to be codified at 7 U.S.C. $\$ 2(a)$ ) (public reporting of swaps); $i d . \$ 733124$ Stat. at 171217 (to be codified at 7 U.S.C. 7b-2) (swap execution facilities); id. § 763, 124 Stat. at 1762-84 (to be codified in subsections of 15 U.S.C. $\$ 78$ ) (clearing of security-based swaps); § 766, 124 Stat. at 1797-99 (to be codified in subsections of 15 U.S.C. $§ 78$ ) (public reporting for security-based swaps and security-based swap execution facilities); see also Ryan J. Maierson, Dodd-Frank Wall Street Reform and Consumer Protection Act: The General Counsel's Quick Reference Guide, in 2010 HOW TO PREPARE FOR THE UpComing Proxy SEASOn at 371, 391-400 (PLI Corp. Law \& Practice, Course Handbook Series No. B-1185, 2010) (describing the effect of Dodd-Frank on the over-thecounter derivatives market that previously was largely unregulated).

${ }^{191}$ Dodd-Frank Act $\S 712$ (b), 124 Stat. at 1642-43 (to be codified at 7 U.S.C. $\S$ 2(a) (1)); id. § 722(a), 124 Stat. at 1642-43 (to be codified at 7 U.S.C. § 2(a)(1)). 
registration, information-reporting, and antifraud provisions of those laws. ${ }^{192}$

The term "swap," which Dodd-Frank added to Commodity Exchange Act (CEA) section $1 \mathrm{a}^{193}$, is broadly defined and overlaps in most respects with the term "swap agreement" in GLBA section 206A, as amended by Dodd-Frank. ${ }^{194}$ It excludes, however, most "securitybased swaps."

Dodd-Frank added the term "security-based swap" to Exchange Act section 3(a) and defined it as an agreement, contract, or transaction that would be a swap (as defined in the CEA), but for the fact that it is based on

(I)an index that is a narrow-based security index, including any interest therein or on the value thereof;

(II) a single security or loan, including any interest therein or on the value thereof; or

(III) the occurrence, nonoccurrence, or extent of the occurrence of an event relating to a single issuer of a security or the issuers of securities in a narrow-based security index, provided that such event directly affects the financial statements, financial condition, or financial obligations of the issuer.

The term "narrow-based security index" is not new; the CFMA in 2000 added it to both the CEA and the Exchange Act. ${ }^{197}$ Put simply, a narrow-based security index is an index with nine or fewer component securities, an index in which one security is weighted more than thirty percent, an index in which the five most highly weighted securities are weighted more than sixty percent, or an index in which the securities in the bottom twenty five percent of the index's total weight have low average daily trading volumes. ${ }^{198}$

19215 U.S.C.A. $\$ 77 \mathrm{~b}(\mathrm{a})$ (1) (West 2011); id. § 78c(a) (10).

193 Pub. L. No. 74-675, 49 Stat. 1491 (1936) (codified as amended at 7 U.S.C. $\$ \$ 1-$ $25(2006))$.

${ }^{194}$ Compare Dodd-Frank Act $\$ 721$ (a) (21), 124 Stat. at 1666-69 (to be codified at 7 U.S.C $\S 1 \mathrm{a}(47))$, with Gramm-Leach-Bliley Act $\$ 206$ A, 15 U.S.C. $\$ 78 \mathrm{c}$ note, amended by Dodd-Frank Act $\S 762$ (b), 124 Stat. at 1759 (to be codified as note to 15 U.S.C. $\$ 78 \mathrm{c})$.

${ }^{195}$ Dodd-Frank Act $\S 721$ (a) (21), 124 Stat. at 1668 (to be codified at 7 U.S.C. $\S$ $1 \mathrm{a}(47)(\mathrm{B})(\mathrm{x}))$.

${ }^{196}$ Id. $\S 761(\mathrm{a})(6), 124$ Stat. at $1756-57$ (to be codified at 15 U.S.C. $\S$ $78(\mathrm{c})(\mathrm{a})(68))$.

${ }^{197} 7$ U.S.C. $§ 1 \mathrm{a}(25)$ (2006); 15 U.S.C. $\$ 78 \mathrm{c}(\mathrm{a})(55)$ (B) (2006).

198 15 U.S.C. $\$ 78 \mathrm{c}$ (a) (55) (B) (2006). A narrow based security index includes one "(iv) in which the lowest weighted component securities, comprising, in the aggregate, 25 percent of the index's weighting have an aggregate dollar value of average daily trading volume of less than $\$ 50,000,000$ (or in the case of an index with 15 or more component securities, $\$ 30,000,000)$." Id. 
Dodd-Frank appropriately recognized that a single agreement, contract, or transaction could have attributes of both a security-based swap (e.g., be based on a single stock) and a swap (e.g., be based on an interest rate, currency, or commodity) and provided that such an agreement, contract, or transaction-what Dodd-Frank refers to as a "mixed swap"-is both a swap and a security-based swap. ${ }^{199}$ Mixed swaps are subject to the broad jurisdiction of both the CFTC and the SEC.

Notwithstanding the sweeping reform and the new jurisdictional division, Dodd-Frank retained the term "security-based swap agreement" and most of the provisions of the Securities Act and the Exchange Act that apply to security-based swap agreements. The reform, however, did make some adjustments. First, it moved the definition of "security-based swap agreement" from GLBA section $206 \mathrm{~B}$ to Exchange Act section 3(a) (78). ${ }^{200}$ Second, although the text of the new Exchange Act definition is substantially the same as the one under GLBA, its scope was curtailed because Exchange Act $\S$ $3(\mathrm{a})(78)$ provides that " $\mathrm{t}]$ he term 'security-based swap agreement' does not include any security-based swap." ${ }^{201}$ Finally, Dodd-Frank modified the meaning of "security-based swap agreement" by amending the definition of the term "swap agreement" in GLBA section $206 \mathrm{~A}$ to include agreements, contracts, and transactions that are not entered into by eligible contract participants and those whose material terms are not subject to individual negotiation. ${ }^{202}$

Under Dodd-Frank, a security-based swap agreement is a "swap," not a "security-based swap.," ${ }^{203}$ As "swaps," security-based swap agree-

199 See Dodd-Frank Act $\$ 721$ (a) (21), 124 Stat. at 1668 (to be codified at 7 U.S.C. $\$$ $1 \mathrm{a}(47)(\mathrm{B})(\mathrm{x}),(\mathrm{D}))$ (including a mixed swap in the definitions of the term "swap"); id. $\S 761$ (a) (6), 124 Stat. at 1757 (to be codified at 15 U.S.C. $\S 78 \mathrm{c}(\mathrm{a})(68)(\mathrm{D})$ ) (including a mixed swap in the definitions of the term "security-based swap").

${ }_{200}$ See Dodd-Frank Act $\S 762$ (a), 124 Stat. at 1759 (repealing Gramm-Leach-Bliley Act $\S 206$ B, 15 U.S.C. $\S 78 c$ note $(2006)$ ); id. $\S 761(\mathrm{a})(6), 124$ Stat. at 1759 (to be codified at 15 U.S.C. $\S 78 \mathrm{c}(\mathrm{a})(78)$ ) (amending Securities Exchange Act of $1934 \S$ 3(a), 15 U.S.C. $\$ 78 c(a)$ (2006), to add the definition of "security-based swap agreement").

$201 \quad 15$ U.S.C.A. $\$ \S 78 \mathrm{c}(\mathrm{a}),(78)$ (B) (West 2011).

${ }^{202}$ Dodd-Frank Act $\$ 762$ (b), 124 Stat. at 1759 (amending Gramm-Leach-Bliley Act $\$ 206$ A, 15 U.S.C. \$ 78c note); see supra note 31 and accompanying text (quoting a portion of GLBA section 206A definition of "swap agreement" before it was amended by Dodd-Frank). Notwithstanding the fact that Dodd-Frank moved the definition of "security-based swap agreement" from the GLBA to the Exchange Act, the definition in the Exchange Act still incorporates the definition of "swap agreement" in GLBA section 206A. 15 U.S.C.A. $§ 78$ c(a) (78) (West 2011).

${ }^{203} 7$ U.S.C.A. $\$ 1 \mathrm{a}(47)(\mathrm{A})(5)$ (West 2011); 15 U.S.C.A $\$ 78 \mathrm{c}(\mathrm{a})(78)$ (B) (West 2011). 
ments generally are subject to CFTC jurisdiction, but through the continuing effectiveness of CFMA amendments, the SEC shares antifraud jurisdiction over them with the CFTC. The nomenclature used by Congress is a recipe for confusion, and Dodd-Frank's legislative history is not very helpful in interpreting any of the three terms. The legislative history includes little more than conclusory statements about the jurisdictional division between the SEC and the CFTC with respect to over-the-counter derivatives. ${ }^{204}$ Unfortunately, SEC Chairman Mary Schapiro's 2009 testimony before the Senate Subcommittee on Securities, Insurance, and Investment does little to help because it describes a jurisdictional scheme different from what Congress finally settled on in Dodd-Frank. In her testimony, Chairman Schapiro distinguished between "securities-related" derivatives and "non-securities-related derivatives":

An [over-the-counter] derivative is "securities-related" when the reference is to an entity that is an issuer of securities (such as a public company), to a security itself (or a related event such as a dividend payment), to a group or index of securities or issuers, or based on related aspects of a security or group or index of securities or issuers, such as price, yield, volatility, dividend payments, or value. . .

$\ldots$

... Securities-related [over-the-counter] derivatives would include equity derivatives and credit and other fixed income derivatives. Non-securities-related derivatives would include interest rate derivatives, foreign currency derivatives, and all non-financial derivatives. $^{205}$

Chairman Schapiro appears to have been recommending that the scope of the term "security-based swap agreement" be expanded and that the SEC's authority with respect to security-based swap agree-

${ }^{204}$ Congressman Peterson described the jurisdictional landscape as follows:

Title VII [of the bill] allocates authority over swaps and security-based swaps as follows. First, the CFTC has exclusive jurisdiction over swaps, including swaps on broadbased security indexes. Within the swap definition is a category of swaps called security-based swap agreements. For this specific category of swaps, the CFTC will continue to exercise its full jurisdictional authority, while the SEC may exercise certain specific authorities over these products, as outlined in Title VII. Title VII also clarifies that the SEC has jurisdiction over security-based swaps, which are swaps on narrow-based security indexes and single securities, and that the two agencies share authority over mixed swaps.

See 156 Cong. REc. H5,256 (daily ed. June 30, 2010) (statement of Rep. Peterson).

205 Schapiro Testimony, supra note 14 , at $45,49$. 
ments be extended beyond antifraud. ${ }^{206}$ Indeed, she suggested that "primary responsibility for 'securities-related' [over-the-counter] derivatives . . be retained by the SEC." ${ }^{207}$ She did not describe a scheme such as the one in Dodd-Frank under which the SEC has comprehensive jurisdiction over derivatives very closely tied to securities and merely antifraud jurisdiction over derivatives more loosely related to securities.

Although Dodd-Frank's legislative history is not very helpful, the reform law provided an opportunity for clarity by directing the CFTC and the SEC jointly to further define the terms "swap," "securitybased swap," and "security-based swap agreement." the CFTC and the SEC accordingly proposed interpretive guidance and, in limited cases, proposed rules with respect to the terms. ${ }^{209}$ The two commissions provided extensive guidance with respect to the terms "swap" and "security-based swap," but stated that they did not believe it "possible to provide a bright line test to define" a securitybased swap agreement and offered only three examples of types of swaps that "clearly fall within the definition." 210 One of the examples-"a swap on an index of securities that is not a narrow-based security index" obvious from reading the statutory definitions of "security-based swap agreement" and "security-based swap" together. As to "security-based swap agreements," then, the likelihood of achieving clarity appears bleak.

${ }^{206}$ See id. at 49 (urging Congress to include "securities-related [over-the-counter] derivatives" in the definition of security and thereby subject those derivatives to broad regulation under the federal securities laws).

207 Id. at 104 (emphasis added).

${ }^{208}$ Dodd-Frank Act, Pub. L. No. 111-203, § 712(d) (1), 124 Stat. 1376, 1644 (2010) (to be codified at 15 U.S.C. $\$ 8302$ ).

${ }^{209}$ See generally Further Definition of "Swap," "Security-Based Swap," and "SecurityBased Swap Agreement"; Mixed Swaps; Security-Based Swap Agreement Recordkeeping, 76 Fed. Reg. 29818 (proposed May 23, 2011) (to be codified at 17 C.F.R. pts. 1, 240) (proposing interpretive guidance and rules regarding the terms "swap," "security-based swap," and "security-based swap agreement").

210 Id. at 29863.

${ }^{211} I d$. 
V. THE Future of the SECURITY-BASEd SWAP AGREEMENT: A CONCEPT WHOSE TIME HAS PASSED OR A BENEFICIAL REMNANT OF A BYGONE ERA?

\section{A. A Concept Whose Time Has Passed}

The spotty-and sparse-history of the term "security-based swap agreement" raises the question of whether the concept is needed or beneficial in Dodd-Frank's new, comprehensive regulatory scheme for over-the-counter derivatives. The provisions in the Securities Act and the Exchange Act with respect to security-based swap agreements no doubt offer some benefits in SEC antifraud enforcement. In light of Dodd-Frank, however, the benefits are limited at best and are outweighed by the difficulties the concept presents. Therefore, for a number of reasons, Congress should eliminate the "security-based swap agreement" concept from the federal securities laws.

1. The Concept Was Used Sparingly Prior to Dodd-Frank and Dodd-Frank Makes the Concept More Inconsequential

Since Congress enacted the CFMA in 2000, cases involving alleged fraud related to security-based swap agreements have been few. The scope of the term was not considered by a court in a substantive way until 2005, when the United States District Court for the District of New Jersey decided St. Matthew's. ${ }^{212}$ It was not until 2008-more than seven years after the CFMA was enacted-that the SEC brought its first enforcement action with respect to an alleged security-based swap agreement in Langford. ${ }^{213}$ It was not until 2010, in Rorech, that a court issued a substantive opinion regarding an SEC enforcement action with respect to a security-based swap agreement. ${ }^{214}$ During its over-ten-year history, therefore, the provisions employing the term have been relatively inconsequential. With the adoption of DoddFrank, they are even more so.

By excluding security-based swaps from the definition, DoddFrank curtailed the scope of the term "security-based swap agreement." As discussed above, other than the exclusion of security-based swaps, the definition is the same as it was prior to the reform act. Consequently, over-the-counter derivatives, such as the swap in St.

\footnotetext{
${ }^{212}$ See supra notes 78-85 and accompanying text (discussing St. Matthew's).

${ }^{213}$ See supra Part III (discussing Langford).

214 See supra Part II.B.1 (discussing Rorech).
} 
Matthew's, which did not satisfy the pre-Dodd-Frank definition, also do not satisfy the post-Dodd-Frank definition. ${ }^{215}$ Some over-thecounter derivatives that previously satisfied the definition of "securitybased swap agreement," however, no longer do so because they fit the definition of "security-based swap." For example, the swaps at issue in Caiola and Rorech satisfied the pre-Dodd-Frank definition, but those same swaps would not satisfy the post-Dodd-Frank definition because they would be considered security-based swaps. ${ }^{216}$

For an agreement, contract or transaction to be a security-based swap:

- the agreement, contract or transaction must be a swap (without taking into account the exclusion of securitybased swaps from the definition of "swap" in CEA section $1 \mathrm{a}(47))$; and

- the swap must be based on any one of the following:

o a narrow-based security index or an interest in or the value of a narrow-based security index;

o a single security or an interest in or the value of a single security;

o a single loan or an interest in or the value of a single loan; or

o a financial event directly affecting a single issuer of a security or the issuers of securities in a narrowbased security index. ${ }^{217}$

${ }^{215}$ See supra notes 84-89 and accompanying text (discussing the swap at issue in St. Matthew's).

216 The interpretive guidance proposed by the CFTC and the SEC confirms that the Ciaola and Rorech swaps would have been security-based swaps. The equity swaps in Ciaola were total return swaps. See Further Definition of "Swap," "Security-Based Swap," and "Security-Based Swap Agreement"; Mixed Swaps; Security-Based Swap Agreement Recordkeeping, 76 Fed. Reg. 29818, 29842 (proposed May 23, 2011) (to be codified at 17 C.F.R. pts. 1, 240) (defining a total return swap as one "in which one counterparty ... makes a payment that is based on the price appreciation and income from an underlying security ... [and $t$ ] he other counterparty . . . makes a financing payment ..., as well as a payment based on the price depreciation of the [security]"); Alex Raskolnikov, The Cost of Norms: Tax Effects of Tacit Understandings, 74 U. CHI. L. REv. 601, 618 n.88 ("An equity swap is a total return swap referencing an equity security or a basket of securities."). According to the CFTC and the SEC, "where a [total return swap] is based on a single security . . , the [total return swap] is a security-based swap." Further Definition of "Swap," "Security-Based Swap," and "Security-Based Swap Agreement"; Mixed Swaps; Security-Based Swap Agreement Recordkeeping, 76 Fed. Reg. at 29842. The guidance similarly provides that a credit default swap, like the one in Rorech, that is "triggered by a [financial] event relating to the issuer ... [is] a security-based swap." Id. at 29843.

217 See 15 U.S.C.A. $\$ 78 c(a)(68)$ (West 2011). 
The meaning of "based on" is an open question under DoddFrank, but the reform Act's amendments to CEA section 4a(a) under section 737, its treatment of so-called "mixed swaps,", ${ }^{218}$ and the interpretive guidance proposed by the CFTC and the SEC provide some insight as to the term. The use of the phrase "directly based on" ${ }^{219}$ in amended CEA section $4 \mathrm{a}(\mathrm{a})(4)(\mathrm{B})$ and the absence of the word "directly" from the definition of "security-based swap" suggest a somewhat flexible interpretation of the term "based on" in the definition of "security-based swap." Moreover, the inclusion of mixed swaps in the definition indicates that "based on" does not require an exclusive relationship. On the other hand, the proposed interpretative guidance indicates that not just any relationship will suffice. The mere fact that a term of an instrument is "informed by [a] value or level of a security, rate, or other commodity at the time of the execution" does not mean that the instrument is a security-based swap. ${ }^{220}$ Considering these points, perhaps Rorech's interpretation of "based on"as requiring a relationship between two items in which one is a "fundamental part or ingredient of, or principal component of" the other-may apply equally to the definition of "security-based swap.",221

The equity swaps in Caiola easily satisfy the definition of securitybased swap. They related to a single security-Philip Morris stockand were the functional equivalent of trading in the security. With equity swaps specifically listed in the definition of "swap" under CEA section $1 \mathrm{a}(47)$, the Caiola equity swaps would have been swaps. In addition, because the Caiola equity swaps were related exclusively to Philip Morris stock, they would be considered "based on" a single security under any interpretation of the phrase.

The CDSs at issue in Rorech also satisfy the definition of securitybased swap. Like equity swaps, CDSs specifically are listed in the CEA "swap" definition. Therefore, the Rorech CDSs would have been swaps. Moreover, payments under the Rorech swaps were triggered on the occurrence of a credit event (which certainly would have been a financial event under the definition of "security-based swap") relating to $\mathrm{VNU}$, a single issuer of bonds, which are securities.

218 See supra note 199 and accompanying text (indicating that instruments that have attributes of both a swap and a security-based swap are treated as both).

${ }^{219}$ Dodd-Frank Act, Pub. L. No. 111-203, § 737(a) (4), 124 Stat. at 1724 (to be codified at 7 U.S.C. $\$ 6 \mathrm{a}(\mathrm{a})(4)$ (B)) (emphasis added).

${ }^{220}$ Further Definition of "Swap," "Security-Based Swap," and "Security-Based Swap Agreement”; Mixed Swaps; Security-Based Swap Agreement Recordkeeping, 76 Fed. Reg. at 29845.

${ }_{221}$ SEC v. Rorech, 720 F. Supp. 2d 367, 405 (S.D.N.Y. 2010). 
As discussed in Part II.B.3, the swaps at issue in Elliott, Wyly, and Goldman Sachs likely satisfied the pre-Dodd-Frank definition of "security-based swap agreement" for the same reasons that the swaps in Caiola and Rorech did. ${ }^{222}$ Because those cases are short on details regarding the mechanics of the swaps at issue, it is difficult to analyze with specificity whether those swaps would meet the definition of "security-based swap" and therefore be excluded from the definition of "security-based swap agreement" post-Dodd-Frank. Nevertheless, given the apparent similarity of the swaps in Elliott and Wyly to those in Caiola and the apparent similarity of the CDSs in Goldman Sachs to the CDSs in Rorech, it seems likely that the swaps in Elliott, Wyly, and Goldman Sachs similarly would be security-based swaps and thus not security-based swap agreements post-Dodd-Frank.

The only other cases dealing with over-the-counter derivatives that met or were alleged to have met the pre-Dodd-Frank definition of "security-based swap agreement" were those in School District of Erie, Langford, and LeCroy, and it is uncertain whether the swaps at issue in those cases would meet the post-Dodd-Frank definition. What is certain is that the School District of Erie swaption would not be a securitybased swap; therefore, it would not be excluded from the post-DoddFrank definition of "security-based swap agreement" for that reason. Although the School District of Erie swaption is not clearly outside the statutory definition of "security-based swap," the interpretive guidance proposed by the CFTC and the SEC confirms that it is in fact excluded. The guidance states that interest rate swaps based solely on LIBOR are not security-based swaps. ${ }^{223}$ Moreover, the guidance makes clear that the mere fact that the fixed rate in the School District of Erie swaption was determined in reference to the related bonds would not be sufficient to make the swaption a security-based swap. ${ }^{224}$

Whether the SIFMA Index swaps in Langford and LeCroy would be security-based swaps, and therefore excluded from the post-DoddFrank definition of "security-based swap agreement," is less clear. The definition of "security-based swap" in Exchange Act section 3 (a) (68) provides that the term "index" means "an index or group of

${ }^{222}$ See supra Part II.B.3 (discussing Elliott, Wyly, and Goldman Sachs).

223 Further Definition of "Swap," "Security-Based Swap," and "Security-Based Swap Agreement”; Mixed Swaps; Security-Based Swap Agreement Recordkeeping, 76 Fed. Reg. at 29840.

${ }^{224}$ See $i d$. at 29845 (stating that the fact that a term of a swap is "informed by the value or level of a security, rate, or other commodity at the time of execution" does not itself determine whether the instrument is a swap or security-based swap, "provided that the . . . term ... is set at the time of execution . . . and the value or level of that fixed term or condition may not vary over the life of the [instrument.]"). 
securities."25 Thus, if the group of VRDOs used to calculate the SIFMA Index is a narrow-based security index and if the SIFMA Index represents an interest in that group or the value of that group for purposes of the definition of "security-based swap," a SIFMA Index swap might be included. ${ }^{226}$

The term "narrow-based security index" was defined by the CFMA in connection with permitting the trading of securities futures in the United States. ${ }^{227}$ Several years after the CFMA was enacted, the SEC and the CFTC noted that "most indexes composed of debt securities... would fall within the statutory definition." this generally inappropriate, the SEC and CFTC adopted Rule 3a55-2 under the Exchange Act to exclude certain debt indexes from the definition. ${ }^{229}$ Under the proposed rules issued by the SEC and the CFTC pursuant to Dodd-Frank, Rule 3a55-2 would apply to the definition of "security-based swap" to the same extent as it applies to the definition of "security future." Without knowing the make-up of the group of over 600 securities used to calculate the SIFMA Index and because the group changes from week to week, it is hard even to speculate whether a particular group would fit within the statutory definition of "narrow-based security index" or qualify for the exclusion under Rule 3a55-2.

${ }^{225} 15$ U.S.C.A. $\$ 78 c(a)(68)$ (E) (West 2011) (emphasis added). The term generally excludes a swap that would be a security-based swap by virtue of being based on an exempted security, but it includes one that is based on a municipal security. Id. $\S$ $78 \mathrm{c}(\mathrm{a})(68)(\mathrm{C})$. The exclusion uses the definitions of "exempted security" and "municipal security" that were in effect when the Futures Trading Act of 1982 was enacted. Id.

${ }^{226}$ In light of the fact that the SIFMA Index is calculated based on a single attribute of the underlying group of securities, an argument that a SIFMA Index swap is based on the underlying group of securities (rather than an interest in or the value of the group) is not viable.

227 See Edward J. Rosen \& Geoffrey B. Goldman, The Commodity Futures Modernization Act of 2000, in SWAPs \& OTHER Derivatives IN 2001, at 573, 579 (PLI Corp. \& Practice Course, Handbook Series No. B-1280 2001) (noting that the CFMA permitted trading in futures on narrow-based securities indexes).

228 Joint Final Rules: Application of Narrow-Based Security Index to Debt Security Indexes and Security Futures on Debt Securities, 71 Fed. Reg. 39534, 39534 (July 13, 2006) (codified at 17 C.F.R. pt. 240).

22917 C.F.R. 240.3a55-2 (2011).

${ }^{230}$ See Further Definition of "Swap," "Security-Based Swap," and "Security-Based Swap Agreement"; Mixed Swaps; Security-Based Swap Agreement Recordkeeping, 76 Fed. Reg. 29818, 29896 (proposed May 23, 2011) (to be codified at 17 CFR pts. 1, 240) (providing that, under Proposed Rule 240.3a68-3(a), the rules and regulations interpreting the term "narrow-based security index" generally apply to the definition of "security-based swap" to the same extent as they apply to the definition of "security future"). 
Whether a SIFMA Index swap would be considered based on an interest in the underlying group or the value of the underlying group is a difficult question. Unlike the definition of "security-based swap agreement," the term "value" in the definition of "security-based swap" refers only to a security or group of securities as a whole, rather than to an interest in a security or group of securities. An interest rate clearly does not represent the value of all of the interests in a security or group of securities, so a SIFMA Index swap should not be a security-based swap for that reason. Whether a SIFMA Index swap might be considered based on an interest in the underlying group of securities is anyone's guess.

Mention of the SIFMA Index is notably absent from the interpretive guidance and rules proposed by the CFTC and the SEC. The guidance states that when an instrument is "based solely on levels of interest rates or other monetary rates that are not themselves based on one or more securities, the instrument would be a swap and not a security-based swap." ${ }^{231}$ It states elsewhere that "if [an] interest rate swap contain[s] additional terms that [are] in fact contingent on a characteristic of [a] debt security, such as an adjustment to future interest rate swap payments based on the future price or yield of the debt security, [the instrument] would be a security-based swap." ${ }^{232}$ Unfortunately, the "guidance" leaves open questions as to whether the group of securities used to calculate the SIFMA Index constitutes a narrow-based security index and, if it does, whether a SIFMA Index swap is based on that group or an interest in that group.

2. The Security-Based Swap Definition Allows Appropriate Allocation of Jurisdiction

The cases involving alleged security-based swap agreements have been at two extremes-those in which SEC jurisdiction is clearly appropriate and those in which SEC jurisdiction is clearly unnecessary. The definition of "security-based swap agreement" at worst results in, and at best leaves uncertain the question of, SEC jurisdiction in cases where such jurisdiction is clearly unnecessary. The definition of "security-based swap," when coupled with the interpretive guidance proposed by the CFTC and the SEC, appears to strike a better balance.

As discussed above, if Dodd-Frank had been in effect when the swaps at issue in Caiola, Rorech, Elliott, Wyly, and Goldman Sachs were entered into, the swaps in Caiola and Rorech would have been, and the

231 Id. at 29840.

${ }^{232} I d$. at 29845 . 
ones in Elliott, Wyly, and Goldman Sachs likely would have been, security-based swaps and therefore subject to SEC jurisdiction. Such a result is appropriate because the types of swaps at issue in those cases present securities-like fraud risks. This is particularly true as to the type of swaps at issue in Caiola, Elliott, and Wyly, which can serve as substitutes for trading in securities. ${ }^{233}$

Similarly, the cost-of-funds swap described in Part III.C, ${ }^{234}$ which also presents securities-like fraud risks, would be a security-based swap and subject to SEC antifraud jurisdiction. Interest rate swaps are specifically listed in the definition of "swap" under CEA section 1a(47), the swap clearly is connected to a single security-the related bondsand although the meaning of "based on" is not entirely clear, the interpretive guidance specifically states that "if [an] interest rate swap contain $[\mathrm{s}]$... terms that are ... contingent on a characteristic of debt security that may change in the future,... then [the instrument] would be a security-based swap." ${ }^{235}$

Unlike the swaps at issue in Caiola, Rorech, Elliott, Wyly, and Goldman Sachs and the cost-of-funds swap described in Part III.C, the swaps at issue in St. Matthew's, School District of Erie, Langford, and LeCroy should not be subject to SEC antifraud jurisdiction because they do not represent securities-like fraud risks. As discussed earlier, it is clear that the School District of Erie swaption would escape the definition of "security-based swap." For the same reasons, the St. Matthew's swap would as well. Unfortunately, that result is not certain with respect to the SIFMA Index swaps at issue in Langford and LeCroy. Nevertheless, it seems more difficult to argue that those swaps satisfy the definition of security-based swap than it is to argue that they are security-based swap agreements. As discussed in Part III.C, one can make a reasonable argument that the SIFMA Index swaps were security-based swap agreements because the SIFMA Index is determined from interest rates that are set based on the prices of the underlying securities (i.e., the VRDOs). In contrast, even assuming that the

${ }^{233}$ See SEC v. Rorech, 720 F. Supp. 2d 367, 400 (S.D.N.Y. 2010) ("CDSs that reference single corporate entities are viewed by market participants as synthetic bond positions in those entities, with the purchase of CDS protection being the equivalent of shorting a corporate bond, and the selling of protection being the equivalent of buying a bond.”); Caiola v. Citibank, N.A., 137 F. Supp. 2d 362, 365 n.1 (S.D.N.Y. 2001) (describing how an equity swap replicates the economics of purchasing a security).

${ }^{234}$ See supra Part III.C (describing an example of a "cost-of-funds" swap).

${ }^{235}$ Further Definition of "Swap," "Security-Based Swap," and "Security-Based Swap Agreement"; Mixed Swaps; Security-Based Swap Agreement Recordkeeping, 76 Fed. Reg. at 29840. 
group of securities used to calculate the SIFMA Index constitutes a narrow-based security index, it would take some mental gymnastics to conclude that the SIFMA Index's composite interest rate represents an interest in that group of underlying securities.

Based on the pre-Dodd-Frank cases that involved alleged security-based swap agreements, allocating antifraud jurisdiction to the SEC using the term "security-based swap" appears to strike a better (or at least a marginally clearer) balance than the term "security-based swap agreement" achieved before the reform act. The swaps at issue in those pre-Dodd-Frank cases that raised securities-like fraud concerns would be security-based swaps subject to broad SEC jurisdiction postDodd-Frank, and the swaps that did not raise those concerns likely would be swaps subject to broad CFTC jurisdiction.

\section{The Term Has Been Poorly Interpreted}

As discussed in Part II.C of this Article, the term "security-based swap agreement" has been poorly interpreted. The St. Matthew's court reached a sweeping conclusion that LIBOR swaps cannot be "security-based swap agreements" and failed to give appropriate attention to the connection between the swap at issue in the case and the related loan agreement. School District of Erie followed suit and virtually ignored the fact that the LIBOR-based swaption at issue in that case had a fixed rate that very likely was determined using the interest rates for related bonds. As a result, School District of Erie never addressed the consequence of having a swap rate equal to an interest rate of a debt security. Because the connection between the swaps and the related loan and bonds in St. Matthew's and School District of Erie did not present securities-type fraud risks with respect to the swaps, the courts in those cases reached appropriate conclusions from a policy perspective. Their cursory analyses, however, bode ill for the future. After St. Matthew's was decided, the courts in School District of Erie and Rorech mindlessly repeated the conclusion that LIBOR-based swaps cannot be security-based swap agreements. If the court in St. Matthew's appropriately had based its holding on the fact that the loan agreement related to the swap was not a security, the court in School District of Erie might have given more studied attention to the fact that the School District of Erie swaption indeed had a connection to a security.

In their recent proposed interpretive guidance, the CFTC and the SEC made clear that the fact that a "fixed term[] or condition[] of [an instrument has been] informed by the value or level of a security, rate, or other commodity at the time of execution of the instru- 
ment" should not have an impact on whether an instrument is a swap or a security-based swap as long as "the fixed term or condition is set at the time of execution ... and the value or level of that fixed term may not vary over the life of the [instrument]." ${ }^{236}$ Consequently, as indicated above, the swaption in School District of Erie would not be a security-based swap even though the fixed rate in the swaption likely was determined by reference to interest rates for the related bonds. ${ }^{237}$ Unfortunately, the commissions provided no similar guidance with respect to security-based swap agreements, leaving the School District of Erie conclusion that the swaption was not a security-based swap agreement open to dispute.

\section{The Term Is Overly Broad}

The fact that one reasonably could conclude that the plain meaning of the term "security-based swap agreement" includes a SIFMA Index swap suggests that the term is overly broad. ${ }^{238}$ As discussed earlier, a SIFMA Index swap does not pose the risks normally associated with securities and therefore does not warrant coverage under the antifraud provisions of the federal securities laws. ${ }^{239}$

Sadly, it appears that the SEC and the CFTC have not corrected the overreaching application of the term "security-based swap agreement" to SIFMA Index swaps in their proposed rulemaking. In their proposed interpretative guidance, the commissions stated that "a swap based on certain ... exempted securities other than municipal securities" clearly is a security-based swap agreement. ${ }^{240}$ Although this might be read to imply that a swap based on a municipal security (which would include the VRDOs used for the SIFMA Index) ${ }^{241}$ is not a security-based swap agreement, the fact that a swap based on ex-

\footnotetext{
${ }^{236}$ See id. at 29818 (proposing interpretive guidance and rules regarding the terms "swap," "security-based swap," and "security-based swap agreement").

${ }^{237}$ See id. at 29840 (providing that swaps based solely on LIBOR are not securitybased swaps).

${ }^{238}$ See supra Part III.C (discussing arguments that a SIFMA Index swap is a security-based swap agreement).

${ }^{239}$ See supra Part III.C (indicating that SIFMA Index swaps ought not be subject to the provisions of the Securities Act and the Exchange Act with respect to securitybased swap agreements).

${ }^{240}$ Further Definition of "Swap," "Security-Based Swap," and "Security-Based Swap Agreement”; Mixed Swaps; Security-Based Swap Agreement Recordkeeping, 76 Fed. Reg. at 29863.

${ }_{241}$ See 15 U.S.C. $\$ 78 c(a)(29)$ (2006) (defining the term "municipal securities"); supra note 158 and accompanying text (noting SIFMA's assertion that municipal bonds are used for the SIFMA Index because they are the only instruments with taxexempt rates).
} 
empted securities other than municipal securities definitively is a security-based swap agreement does not necessarily mean that one based on municipal securities is not. The fact that the commissions left this question open is not surprising. Both Langford and LeCroy were still pending when the proposed guidance and rules were published, and it is extremely unlikely that the SEC would propose or adopt a rule that might compromise its litigation position. Langford has already been decided, but even if the litigation in LeCroy concludes by the time the final rules are adopted, it seems doubtful that the SEC will adopt a rule contrary to its position in those cases.

Fortunately, Dodd-Frank may have given a measure of relief from rigid interpretations of the term "security-based swap agreement." Although seemingly insignificant, Dodd-Frank's movement of the definition from GLBA section 206B to Exchange Act section 3(a) may allow for a more flexible interpretation of the term. The introductory language preceding all of the definitions under Exchange Act section 3(a) states "unless the context otherwise requires." ${ }^{242}$ No similar language applies to GLBA section 206B. Arguably, Exchange Act section 3(a)'s introductory language gives courts room to apply policy-based reasoning in interpreting Exchange Act definitions. Unlike the court in LeCroy, then, a court considering a SIFMA Index swap under the post-Dodd Frank definition of "security-based swap agreement" seems to have the flexibility to determine that, notwithstanding the fact that the swap satisfies a strict interpretation of the definitional text, the swap in fact does not satisfy the definition because its connection to a security is inconsequential for antifraud purposes.

\section{The Concept Is Redundant}

The CFMA created a federal regulatory void, one in which most over-the-counter derivatives were not subject to the provisions of either the federal securities laws or commodities laws. ${ }^{243}$ In order to

$242 \S 78 \mathrm{c}(\mathrm{a})$.

${ }^{243}$ See id. $\S 77 \mathrm{~b}-1$ (a) (providing that non-security-based swap agreements were not securities); $i d$. 78c-1(a) (same). The CFMA added two provisions to the CEA that were intended to-and clearly did-exclude most swaps from the CEA. Section 2(d) (1) of the CEA excluded from most provisions of the Act, any agreement, contract, or transaction in an excluded commodity if the agreement, contract, or transaction is entered into only between persons that are eligible contract participants and is not executed or traded on a trading facility. 7 U.S.C. $\$ 2$ (d) (1) (2006). Section $2(\mathrm{~g})$ similarly excluded from most provisions of the CEA any agreement, contract, or transaction in a commodity other than an agricultural commodity if the agreement is entered into only between persons that are eligible contract partici- 
make sure that appropriate antifraud enforcement would be available in circumstances related to securities, it made sense for Congress to cast a wide net with the term "security-based swap agreement" and capture some transactions that really are not significant to the securities markets. In the context of Dodd-Frank's sweeping regulation of the over-the-counter derivatives market, however, such overly broad SEC antifraud jurisdiction is no longer necessary. After Dodd-Frank, there is no federal regulatory void. By dividing the world of over-thecounter derivatives into swaps and security-based swaps, Congress made sure that the CFTC's jurisdiction picks up where the SEC's jurisdiction leaves off.

In Dodd-Frank, Congress amended CEA section 6(c) to prohibit, "in connection with any swap, ... any manipulative or deceptive device or contrivance ... in contravention of such rules and regulations as the [CFTC] shall promulgate." ${ }^{244}$ Because of the similarity between the language in CEA section 6(c) and that in Exchange Act section 10(b), the CFTC has adopted a rule "model[ed] ... on SEC Rule 10b-5." ${ }^{245}$ Moreover, Congress's amendment of CEA section 22 (a) (1) grants a private cause of action with respect to swaps. ${ }^{246}$ With DoddFrank's changes to the CEA and the CFTC's new rule, security-based swap agreements are subject to the antifraud jurisdiction of two federal agencies and private litigants have very similar recourse under both the CEA and the Exchange Act. The continuing application of Exchange Act section 10(b) and Rule 10b-5 to security-based swap agreements, therefore, leaves a redundancy.

The proposed guidance and rules published by the SEC and the CFTC seem to indicate that even the commissions themselves have found that the "security-based swap agreement" concept is redundant. The two commissions declined Congress's invitation to adopt rules governing books and records for security-based swap agreements and asserted that the CFTC's rules governing swaps generally are sufficient for security-based swap agreements. ${ }^{247}$ Furthermore, out

pants, is subject to individual negotiation and is not executed on a trading facility. Id. $\S 2(\mathrm{~g})$.

${ }^{244}$ Dodd-Frank Act, Pub. L. No. 111-203, § 753(a), 124 Stat. 1376, 1750 (2010) (to be codified at 7 U.S.C. $\$ 9(c)(1))$.

${ }^{245}$ Prohibition on the Employment, or Attempted Employment, of Manipulative and Deceptive Devices and Prohibition of Price Manipulation, 76 Fed. Reg. 41,398, 41,399 (July 14, 2011) (to be codified at 17 C.F.R. pt. 180).

${ }^{246}$ Dodd-Frank Act $\S 753$ (c), 124 Stat. at 1754 (to be codified at 7 U.S.C. $\S$ $25(\mathrm{a})(1)(\mathrm{D}))$.

${ }^{247}$ Further Definition of "Swap," "Security-Based Swap," and "Security-Based Swap Agreement”; Mixed Swaps; Security-Based Swap Agreement Recordkeeping, 76 Fed. 
[Vol. 42:953

of over eighty pages of proposed rules and interpretive guidance, the commissions devoted only two paragraphs to the definition of the term "security-based swap agreement," and they indicated that they had received no comments with respect to the definition of the term and had not "been made aware of any significant market confusion over what constitutes a [security-based swap agreement]." ${ }^{248}$ The lack of commentary indicates that market participants do not care. PostDodd-Frank, virtually all over-the-counter derivatives are subject to broad federal antifraud statutes. It is no longer a question of whether there is antifraud jurisdiction. It is now a question of who has it.

\section{The Term Creates Confusion}

Although it certainly is not the most important reason to eliminate the "security-based swap agreement" concept from the Securities Act and the Exchange Act, having both "security-based swaps" and "security-based swap agreements" in the same regulatory regime creates the potential for confusion. If Congress wanted to retain the term "security-based swap agreement," it should have been more creative in the names it gave in Dodd-Frank to the over-the-counter derivatives subject to broad SEC jurisdiction and those subject to broad CFTC jurisdiction. A footnote in the District Court's opinion in $\mathrm{El}$ liott may be a preview of the confusion that could be forthcoming. In that case, the court suggested that the reform broadened the meaning of "security-based swap." ${ }^{249}$ Dodd-Frank, of course, did no such thing. The term "security-based swap" is a new term, and the term "security-based swap agreement" was narrowed in the reform.

Much needs to be done to understand the scope of the new regulatory scheme. Notwithstanding the fact that the CFTC and the SEC did not receive comments on the definition of "security-based swap agreement," the term has been a source of confusion in the past-as St. Matthew's, School District of Erie, Langford, and LeCroy evidence. Its continuing role alongside a new term with a substantially similar name only creates the possibility of more confusion.

Reg. 29818, 29863 (proposed May 23, 2011) (to be codified at 17 C.F.R. pts. 1, 240); see supra note 203 and accompanying text (noting that, under Dodd-Frank, a securitybased swap agreement is a type of "swap").

${ }^{248}$ Further Definition of "Swap," "Security-Based Swap," and "Security-Based Swap Agreement”; Mixed Swaps; Security-Based Swap Agreement Recordkeeping, 76 Fed. Reg. at 29862-63.

${ }_{249}$ See Elliott Assocs. v. Porsche Auto. Holding SE, 759 F. Supp. 2d 469, 475 n.3 (S.D.N.Y. 2010) (referencing the financial reform and the term "security-based swap"). 


\section{B. A Beneficial Remnant of a Bygone Era?}

Perhaps Congress merely was being pragmatic in leaving the term "security-based swap agreement" and its associated provisions in place. For over thirty years, the SEC and the CFTC have engaged in a turf war. $^{250}$ In 1975, the SEC challenged the CFTC's exclusive jurisdiction over futures contracts involving securities. ${ }^{251}$ In 1981, the SEC asserted exclusive jurisdiction over "options on securities traded on a national securities exchange" and provoked a lawsuit by the Chicago Board of Trade, which claimed the CFTC had exclusive jurisdiction. ${ }^{252}$ In 1982, the SEC and the CFTC resolved some jurisdictional disagreements through the Shad-Johnson Accord, which Congress subsequently enacted, ${ }^{253}$ but in the late 1980 s, a jurisdictional dispute arose again over stock index participation instruments. ${ }^{254}$ Although the United States Court of Appeals for the Seventh Circuit resolved the dispute in favor of exclusive CFTC jurisdiction and "concluded that the premise under the [Shad-Johnson Accord] was that if an instrument can be classified as both a security and a futures contract, exclusive jurisdiction lies with the CFTC," jurisdictional disputes continued.

By keeping the security-based swap agreement concept in place and giving the SEC and the CFTC joint rulemaking authority to define it, Congress may have been trying to leave an easy venue for compromise and a solution that could mitigate jurisdictional disputes. Specifically, Congress may have intended that the two commissions include in the scope of the term "security-based swap agreement" derivatives with respect to which the commissions disagreed as to jurisdiction. By doing so, those derivatives would be subject to the general jurisdiction of the CFTC and the SEC would have

${ }^{250}$ See 2 JoHnson \& HAZEN, supra note $8, \S 4.05$ [8], [9], at 1000-11 (recounting the SEC's challenges to the CFTC's jurisdiction); Jerry W. Markham, Merging the SEC and CFTC-A Clash of Cultures, 78 U. Cin. L. REv. 537, 552 (2009) ("The SEC and CFTC have a history of clashing over their respective jurisdictions, and their regulatory approaches are often sharply distinctive and incompatible.").

2512 JOHNSON \& HAZEN, supra note $8, \S 4.05$ [8], at 1000 .

${ }^{252}$ Id. $\$ 4.05[8]$, at 1000-01 (citing Bd. of Trade of Chi. v. SEC, 677 F.2d 1137 (7th Cir. 1982), vacated as moot, 459 U.S. 1026 (1982)).

${ }^{253}$ Markham, supra note 250, at 569. For the codification of the accord, see Futures Trading Act of 1982, Pub. L. No. 97-444, 96 Stat. 2294 (codified in scattered sections of 7, 15, and 29 U.S.C.).

2542 JOHNSON \& HAZEN, supra note 8, § 4.05[8], at 1008 .

${ }^{255}$ Id. $\$ 4.05$ [8], at 1009 (quoting Chi. Mercantile Exch. v. SEC, 883 F.2d 537 (7th Cir. 1989)). 
concurrent antifraud jurisdiction. $^{256}$ If this was Congress's intent, however, the CFTC and the SEC have not used their rulemaking authority in that way. ${ }^{257}$

In addition, concurrent jurisdiction might be viewed as beneficial in light of the different regulatory approaches taken by the SEC and the CFTC. "[F] utures regulation has been preoccupied with the protection of the commercial uses and benefits of those markets, while securities regulation has focused primarily on protection for the investment-minded public." ${ }^{258}$ These historical focuses suggest that the SEC may be more adept at antifraud enforcement than the CFTC and that therefore the market would benefit by the SEC's retaining its antifraud jurisdiction over security-based swap agreements even though such jurisdiction would be concurrent with the CFTC's broad jurisdiction over those instruments.

Of course, the SEC has had this antifraud jurisdiction for over ten years and has used it only five times. Even so, one might argue that there is no harm-and that there could be some benefit-in leaving the SEC with antifraud jurisdiction over security-based swap agreements. Such jurisdiction certainly gives the SEC more latitude in its enforcement efforts, and having security-based swap agreements subject to the antifraud provisions of both the securities laws and the commodities laws might create a stronger deterrent effect. ${ }^{259}$

On the other hand, giving overly broad and unnecessary jurisdiction to the SEC can stretch the SEC too thin. It can result, for example, in the SEC's being slow to stop the mastermind of a multibillion dollar Ponzi scheme, ${ }^{260}$ while pursuing antifraud enforcement against a stockbroker who misappropriated a mere $\$ 343,000$ of his

${ }^{256}$ See supra Part IV (indicating that a security-based swap agreement is subject to SEC antifraud jurisdiction, but it also is a "swap," which is subject to the general jurisdiction of the CFTC)

${ }^{257}$ See supra note 210 and accompanying text (noting the limited attention that the CFTC and the SEC have given to the security-based swap agreements).

258 2 JOHNSON \& HAZEN, supra note 8, § 4.05[9], at 1011.

${ }^{259}$ Indeed, CFTC Chairman Gary Gensler has suggested that, for some over-thecounter derivatives, the SEC and the CFTC "will share jurisdiction"-that " $[\mathrm{t}]$ here will be two cops on the beat." Yin Wilczek, CFTC, SEC to Face Challenges in Defining Jurisdiction Over OTC Swaps, Gensler Says, BNA SEC. L. DAILY, Nov. 15, 2010.

${ }^{260}$ See Yin Wilczek \& Phyllis Diamond, 2010 Will Be Important for SEC Enforcers as Division Continues to Rebuild Reputation, BNA SEC. L. DAILY, Jan. 25, 2010 (noting that the SEC failed to uncover Bernard Madoff's $\$ 50$ billion Ponzi scheme); Cox Says Staff Saw Red Flags with Madoff But Failed to Alert Full Commission to Act, BNA SEC. L. DAILY, Dec. 17, 2008 (indicating that the SEC had received credible information about the Madoff scheme as early as 1999, but failed to act). 
clients' assets. $^{261}$ This risk of misallocation of resources is particularly relevant when resources are limited. With the House Appropriations Committee's approving funding for the SEC in fiscal year 2012 equal to that in 2011 and over $\$ 220$ million less than what the President requested, ${ }^{262}$ the SEC needs to focus on smart regulation, not more regulation, and Congress needs to help the SEC do so.

Moreover, concurrent jurisdiction leads to the risk that neither agency will take up enforcement with respect to wrongdoing or that they will duplicate their efforts. In some situations, one agency may fail to act based on the assumption that the other will do so. In others, both agencies may act, which could result in wasteful duplication of efforts. With mammoth deficits saddling the United States, regulation needs to be efficient.

\section{CONCLUSION}

Prior to Dodd-Frank, over-the-counter derivatives were largely unregulated by the federal securities laws. In general, the onerous registration and information-reporting requirements of the Securities Act and the Exchange Act did not apply to them, and only over-thecounter derivatives that met the definition of "security-based swap agreement" were subject to the antifraud provisions of Securities Act section 17(a) and Exchange Act section 10(b) and Rule 10b-5. Congress changed all of that when it enacted Dodd-Frank. With the reform Act, Congress put in place a new and extensive regulatory scheme for the over-the-counter derivatives market. Rather than doing away with the "security-based swap agreement" concept when it crafted Dodd-Frank, however, Congress incorporated it. That was a mistake.

The "security-based swap agreement" concept is fraught with problems. Since 2000, when the concept first was introduced, the SEC has brought related enforcement actions only five times, and very few courts have considered the meaning of the term. Unfortunately, two courts have interpreted the term poorly, and there is a risk that those poor interpretations will be perpetuated. In addition, the definition of the term "security-based swap agreement" is overly broad, arguably capturing swaps that do not raise securities-like fraud risks. Moreover, retaining the concept in the Dodd-Frank scheme re-

${ }^{261}$ See SEC v. Zandford, 535 U.S. 813, 816 (2002) (representing an enforcement action under Exchange Act section 10 (b) and Rule 10b-5 with respect to the misappropriation by a stockbroker of $\$ 343,000$ of his clients' assets).

${ }_{262}$ House Committee Passes Bill to Fund SEC, in FY 2012, at FY 2011 Levels, BNA SEC. L. DAILY (June 24, 2011). 
[Vol. 42:953

sults in redundant antifraud jurisdiction that could prove costly and wasteful at a time when government resources are running thin. Finally, the concept creates confusion in the already extremely complex Dodd-Frank regulatory apparatus.

When Congress enacted Dodd-Frank, it should have recognized these problems and erased the "security-based swap agreement" concept from the federal securities laws. The eraser is still handy. It is time for Congress to use it. 